\title{
An Open-Source Toolbox for Multiphase Flow Simulation in a PEM Fuel Cell
}

\author{
Jean-Paul Kone ${ }^{1}$, Xinyu Zhang ${ }^{1,2}$, Yuying Yan $^{2,3} \&$ Stephen Adegbite ${ }^{2,4}$ \\ ${ }^{1}$ International Doctoral Innovation Centre, University of Nottingham, Ningbo, China \\ ${ }^{2}$ Research Centre for Fluids and Thermal Engineering, University of Nottingham, Ningbo, China \\ ${ }^{3}$ Fluids \& Thermal Engineering Research Group, University of Nottingham, Nottingham, United Kingdom \\ ${ }^{4}$ Department of Chemical and Environmental Engineering, University of Nottingham, Ningbo, China \\ Correspondence: Jean-Paul Kone \& Xinyu Zhang, International Doctoral Innovation Centre, University of \\ Nottingham, Ningbo 315100, China. Tel: 86-152-5838-3974(J.P.K.); 86-180-5826-1662(X.Z.). E-mail: Jean- \\ Paul.KONE@nottingham.edu.cn (J. P. K.); Xinyu.Zhang@nottingham.edu.cn (X.Z.)
}

\author{
Received: April 19, 2018 \\ Accepted: May 2, 2018 \\ Online Published: May 21, 2018 \\ doi:10.5539/cis.v11n3p10 \\ URL: https://doi.org/10.5539/cis.v11n3p10
}

\begin{abstract}
A proton exchange membrane (PEM) fuel cell is an electrolytic cell that can convert chemical energy of hydrogen reacting with oxygen into electrical energy with no greenhouse gases generated in the process. To satisfy increasingly demanding application needs, providing fuel cells with better performance and higher efficiency are of paramount importance. Computational fluid dynamics (CFD) analysis is an ideal method for fuel cell design optimization. In this paper, a comprehensive CFD-based numerical tool that can accurately simulate multiphase flow and the major transport phenomena occurring in a PEM fuel cell is presented. The tool is developed using the Open Source Field Operation and Manipulation (OpenFOAM) software (a free open-source CFD code). This makes it flexible and suitable for use by fuel cell manufacturers and researchers to get an in-depth understanding of the cell working processes to optimize the design. The distributions of velocity, pressure, chemical species, Nernst potential, current density, and temperature at case study conditions are as expected. The polarization curve follows the same trend as those of the I-V curves from numerical model and experimental data taken from the literature. Furthermore, a parametric study showed the key role played by the concentration constant in shaping the cell polarization curve. The developed toolbox is well-suited for research and development which is not always the case with commercial code. The work therefore contributes to achieving the objectives outlined in the International Energy Agency (IEA) Advanced Fuel Cell Annex 37 which promotes open-source code modelling of fuel cells. The source code can be accessed at http://dx.doi.org/10.17632/c743sh73j8.1.
\end{abstract}

Keywords: code, computational fluid dynamics, modelling, multiphase flow, open-source, proton exchange membrane fuel cell, simulation, toolbox

\section{Introduction}

Owing to their higher power densities, lower operating temperatures, and zero emission, proton exchange membrane (PEM) fuel cells have become an integral part of the energy mix schemes of many countries across the globe. In fact, they are poised to replace some of the conventional power generation devices which depend on fossil fuels.

While carbon-based fuel energy conversion devices require various thermodynamic cycles to convert the energy stored in the fuel into useful work, PEM fuel cells can directly convert chemical energy of the fuel into productive work without involving any thermodynamic cycle. As a result, PEM fuel cells have higher efficiencies in direct electrical energy conversion. Moreover, their higher power densities and lower operating temperatures make them appropriate for automotive power systems, as well as power generation devices for portable electronics and stationary units (Kone, Zhang, Yan, Hu, \& Ahmadi, 2017b).

Nevertheless, the excessive costs associated with the manufacturing and performance test of PEM fuel cells often render experimental studies uneconomical. Therefore, most research work on PEM fuel cells is concerned with improving cell performance by maximising efficiency while minimising manufacturing and test costs through computational fluid dynamics (CFD) analyses (Ferreira, Falcao, Oliveira, \& Pinto, 2015; Kone et al., 2017b; Weber 
et al., 2014; Wilberforce et al., 2017; Wu, 2016). The current state-of-the-art work is focused on the effects of modelling parameters on cell polarization (Ashrafi \& Shams, 2017; Khazaee \& Sabadbafan, 2016a, 2016b; Laoun, Naceur, Khellaf, \& Kannan, 2016; Osanloo, Mohammadi-Ahmar, \& Solati, 2016; Ozen, Timurkutluk, \& Altinisik, 2016; Sezgin, Caglayan, Devrim, Steenberg, \& Eroglu, 2016; Velisala \& Srinivasulu, 2018; Y. L. Wang, Wang, Wang, \& Yue, 2018; L. Xing et al., 2016; Zehtabiyan-Rezaie, Arefian, Kermani, Noughabi, \& Abdollahzadeh, 2017; Zhao, Dou, Zhou, \& Gao, 2016). Open-source modelling of PEM fuel cells using OpenFOAM has been performed in previous studies (Barreras, Lozano, Valino, Mustafa, \& Marin, 2008; Imbrioscia \& Fasoli, 2014; Lozano, Valino, Barreras, \& Mustata, 2008; Mustata, Valino, Barreras, Gil, \& Lozano, 2009; Valino, Mustata, \& Duenas, 2014; Valino, Mustata, Gil, \& Martin, 2010). While transport in PEM fuel cells is three dimensional (3D) in nature, the models in (Barreras et al., 2008) and (Lozano et al., 2008) are two dimensional (2-D) and they are only concerned with the bipolar plates. Although the models in (Mustata et al., 2009), (Valino et al., 2010) and (Imbrioscia \& Fasoli, 2014) are 3-D, they are also limited to the bipolar plates and neglect the coupling of transport phenomena in the multiple regions of the fuel cell. The 3-D models in (Valino et al., 2014) considers all fuel cell components but assumes single-phase flow, and isothermal condition meaning that the energy equation is not solved, which can lead to unrealistic results. Like commercial software, the source codes of the models are not available in the public domain, and thus, they offer no flexibility.

In this work, a 3-D, non-isothermal and multiphase flow OpenFOAM model of a complete cell (including all fuel cell components) is developed and validated. The work aims at filling the research knowledge gap in comprehensive open-source modelling approaches for PEM fuel cells. The model developed is an extension of an existing 3-D non-isothermal single-phase flow model introduced in a previous work (Kone, Zhang, Yan, Hu, \& Ahmadi, 2017a) to include liquid water formation, transport, and their effects in PEM fuel cells. The moisture diffusion approach of multiphase flow modelling in a PEM fuel cell based on the unsaturated theory as described elsewhere (Kone et al., 2017b) has been adopted. It is believed that this modelling approach is more appropriate since it only requires one additional governing equation to the existing single-phase flow model. As for the mixture quantities, these are calculated according to the multiphase mixture model (Kone et al., 2017b). Like the previous model (Kone et al., 2017a), the present model has been developed using OpenFOAM version 4.0.

\section{Mathematical model}

\subsection{Multi-Regions and Multi-Physics}

The 3-D geometry and mesh of the fuel cell are shown in Figure 1 and the detailed dimensions of the components are given in Table 1. The model consists of two bipolar plates and a membrane electrode assembly (MEA). The bipolar plates accommodate the gas flow channels. The MEA comprises of a membrane with a negatively charged electrode (anode) attached on one side and a positively charged electrode (cathode) attached on the other side. The electrodes are each made up of a gas diffusion layer and a catalyst layer. For converting chemical energy into electrical energy, hydrogen is fed to the cell on the anode side while oxygen is supplied on the cathode side. It is the electrochemical reactions between these two gases and the catalyst particles which provide the electrical energy.

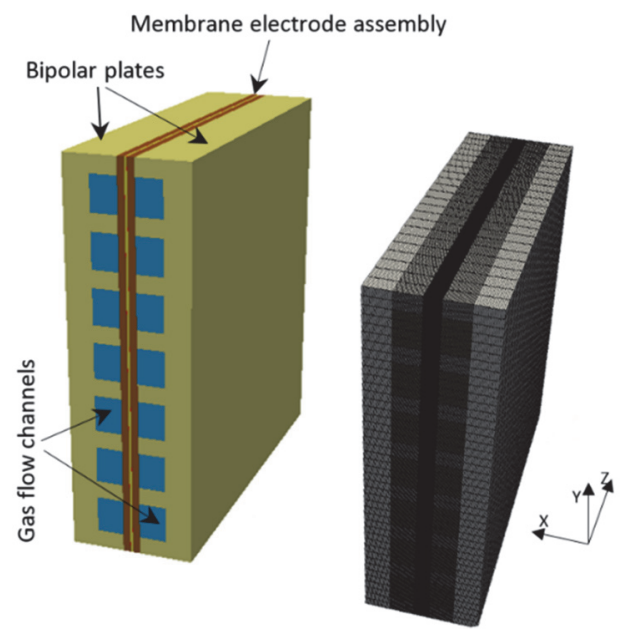

Figure 1. Geometry and mesh of a single cell PEM fuel cell 
Table 1. The cell geometric dimensions

\begin{tabular}{llllll}
\hline & Membrane & Catalyst layer & Gas diffusion layer & Bipolar plate & Gas flow channel \\
\hline x-width $(\mathrm{mm})$ & 0.127 & 0.0037 & 0.41 & 3 & 1.5 \\
y-height $(\mathrm{mm})$ & 22 & 22 & 22 & 22 & 2 \\
z-length $(\mathrm{mm})$ & 22 & 22 & 22 & 22 & 22 \\
\hline
\end{tabular}

Since the physical quantities transported within the fluid and solid regions of a PEM fuel cell are different, the conservation equations that need to be solved in these regions can therefore vary. As shown in Figure 2, the fluid region encompasses the gas flow channels, the gas diffusion layers, and the catalyst layers, whereas the membrane and the bipolar plates make up the solid region. The reactants are transported in the gas flow channels to the gas diffusion layers and then to the surface of the catalyst layers. The product water moves from the surface of the catalyst layers into the pores of the gas diffusion layers where it is then transported into the gas flow channels. The porous structure of the gas diffusion and catalyst layers facilitates the removal of the heat generated by the electrochemical reactions towards the cooling system attached to the bipolar plates. Thus, the conservation of energy applies in both the fluid and the solid regions. But the conservations of mass, momentum, and chemical species are applicable in the fluid regions only. The conservation equations are coupled with the solution of Nernst equation. This means that the transport of mass, momentum, and chemical species are coupled with electrochemical reactions. The solution of the energy equation in the solid region is coupled with the energy solutions in the fluid region.

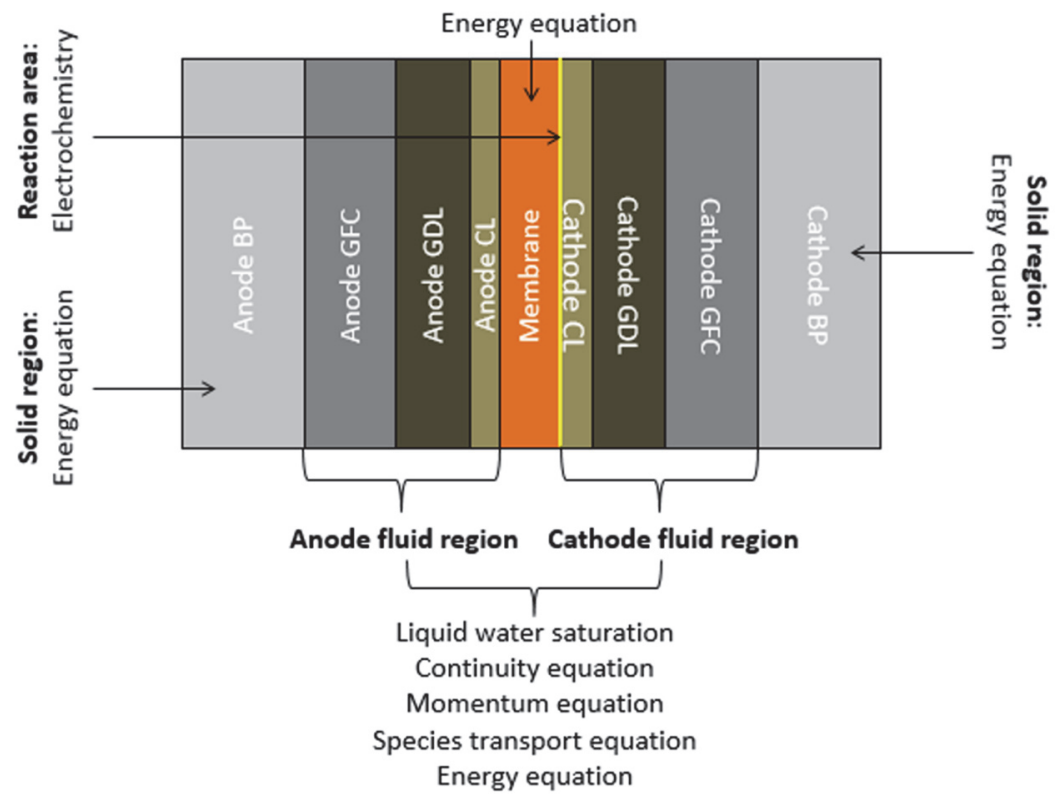

Figure 2. Transport processes in a PEM fuel cell

\subsection{Assumptions}

For the present model, the fuel cell components are treated as homogeneous and isotropic materials. No reactant gases can permeate the membrane. The electrochemical reactions are assumed to occur at the membrane-catalyst layer interface (Beale et al., 2016). Activation and concentration overpotentials are neglected in the anode side (Barbir, 2005). In the bipolar plates, joule heating is neglected because of high heat conductivity and the electrical potential distribution is assumed to be constant because of high electrical conductivity of the bipolar plate material (Ju, Meng, \& Wang, 2005; Sivertsen \& Djilali, 2005). The gas flow is treated as laminar and incompressible due to low velocities at steady-state operating conditions. The individual gases and the gas mixture are treated as ideal gases. No heat enters or leaves through the outer walls of the entire cell (Beale et al., 2016). The two-phase mixture is considered as a fine mist, and thus, the velocity of the liquid is equal to the velocity of the gas inside the gas flow channels where the two phases share the same pressure and temperature fields. Water vapour is assumed to be in equilibrium with liquid water at the interface separating the two. The liquid phase consists of liquid water 
only.

\subsection{Governing Equations}

The conservation of mass is expressed as:

$$
\nabla \cdot\left(\rho_{g} \vec{U}_{g}\right)+S_{l}=0
$$

The conservation of momentum using Navier-Stokes equations reads:

$$
\nabla \cdot\left(\rho_{g} \vec{U}_{g} \vec{U}_{g}\right)=-\nabla p_{g}+\nabla \cdot\left(\mu_{g} \nabla \vec{U}_{g}\right)+S_{M}
$$

where the momentum source term $S_{M}$, is equal to Darcy resistance in the porous media given by:

$$
S_{M}=-\frac{\mu_{g} \vec{U}_{g}}{K_{g}}
$$

The conservation of chemical species is expressed as:

$$
\nabla \cdot\left(\rho_{g} \vec{U}_{g} y_{i}\right)=\left(\nabla \cdot \rho_{g} D_{g}^{e f f} \nabla y_{i}\right)
$$

where the sum of the mass fractions of the other species is used to calculate the mass fraction of the inert species in each electrode, $y_{n}=1-\sum_{i=1}^{n-1} y_{i}$

The conservation of energy reads:

$$
\nabla \cdot\left(\rho_{\text {mix }} c_{p_{\text {mix }}} \vec{U}_{g} T\right)=\nabla \cdot\left(k_{\text {mix }} \nabla T\right)+S_{E}^{\text {reac }}+S_{E}^{P C}
$$

where $S_{E}^{\text {reac }}$ and $S_{E}^{P C}$ are the energy source terms due to the heat released by the electrochemical reactions and water phase change, respectively.

$$
\begin{gathered}
S_{E}^{r e a c}=\frac{I}{\delta_{M E A}}\left(\eta-\frac{T \Delta S}{n_{i} F}\right) \\
S_{E}^{P C}=S_{l} h_{m f g}
\end{gathered}
$$

Liquid water transport is written as (Lei Xing et al., 2014):

$$
\nabla \cdot\left(\rho_{l} D_{l} \nabla s\right)-\nabla \cdot\left(\rho_{g} \vec{U}_{g} s\right)-S_{l}=0
$$

where $D_{l}$ and $S_{l}$ are the diffusivity of liquid water and the mass source term due to phase change, respectively

$$
\begin{gathered}
D_{l}=\frac{\rho_{l} k_{l}}{\mu_{l}} \frac{\partial p_{c}}{\partial s} \\
S_{l}=-C_{r} \frac{\varepsilon(1-s)\left(x_{W V} p_{g}-p_{s a t}\right)}{R T} M_{H_{2} O}
\end{gathered}
$$

The cell voltage is expressed as:

\subsection{Constitutive Equations}

$$
V_{\text {cell }}=E_{\text {Nernst }}-\eta_{\text {act }}-\eta_{\text {ohm }}-\eta_{\text {con }}
$$

The fluid densities are obtained using the ideal gas assumption as follows:

$$
\rho_{g}=\frac{p_{g}}{R T \sum y_{i} / M_{i}}
$$

The molar fraction is related to the mass fraction by:

The specific heat capacity of the gas mixture is defined by:

$$
x_{i}=\frac{y_{i}}{M_{i} \sum y_{j} / M_{j}}
$$

$$
c_{p_{g}}=\frac{c_{p_{m o l}}}{10^{-3} \sum y_{i} * M_{i}}
$$

where $c_{p_{m o l}}$ is the molar heat capacity determined by (Todd \& Young, 2002):

$$
c_{p_{\text {mol }}}(T)=\sum_{i=1}^{n} x_{i} c_{p i}(T)
$$

The thermal conductivity of the gas mixture is calculated using Wassiljewa's expression (Poling, Prausnitz, \& O'Connell, 2000): 


$$
k_{g}=\sum_{i=1}^{n} \frac{x_{i} k_{i}}{\sum_{j=1}^{n} x_{i} A_{i j}}
$$

The dynamic viscosity of the gas mixture is obtained using Reichenberg's expression (Poling et al., 2000):

$$
\mu_{g}=10^{-7} \sum_{i=1}^{n} K_{i}\left(1+2 \sum_{j=1}^{i-1} H_{i j} K_{j}+\sum_{j=1 \neq i}^{n} \sum_{k=1 \neq i}^{n} H_{i j} H_{i k} K_{j} K_{k}\right)
$$

The diffusion coefficient of a gas species $i$ with respect to the total gas mixture in an ordinary diffusion is calculated by (Fairbanks \& Wilke, 1950):

$$
D_{i-m i x}=\frac{1-x_{i}}{\sum_{j \neq i} x_{j}}
$$

where the binary diffusion coefficient $D_{j i}$ for each component of the gas mixture is obtained by (Fuller, Schettle.Pd, \& Giddings, 1966):

$$
D_{j i}=10^{-4} \times \frac{10^{-3} \times T^{1.75}\left(1 / M_{j}+1 / M_{i}\right)^{1 / 2}}{p\left[\left(v_{j}\right)^{1 / 3}+\left(v_{i}\right)^{1 / 3}\right]^{2}}
$$

For simultaneous ordinary and Knudsen diffusion in the porous structure of the gas diffusion layer and the catalyst layer, the effective global-diffusion coefficient is defined as (Welty, Wicks, Wilson, \& Rorrer, c2008):

$$
\frac{1}{D_{\mathrm{i}}^{\text {eff }}}=\frac{1}{D_{i-\text { mix }}^{\text {eff }}}+\frac{1}{D_{i-\text { Knud }}^{\text {eff }}}
$$

$D_{i-m i x}^{e f f}$ is the effective diffusion coefficient of the individual species of the gas mixture in the porous medium and it is expressed as follows (Welty et al., c2008):

$$
D_{i-m i x}^{e f f}=\frac{\varepsilon}{\tau} D_{i-m i x}
$$

Likewise, the effective Knudsen diffusion coefficient of the individual species is expressed as:

$$
D_{\mathrm{i}-\text { Knud }}^{e f f}=\frac{\varepsilon}{\tau} D_{i-\text { Knud }}
$$

where the Knudsen diffusion coefficient of a species $i, D_{i-K n u d}$, is given by (Geankoplis, 1993):

$$
D_{i-K n u d}=97 \times \frac{d_{p}}{2}\left(\frac{T}{M_{i}}\right)^{1 / 2}
$$

The local open-circuit or ideal potential given by the Nernst equation, reads:

$$
E=E_{0}+\frac{R T}{z F} \ln Q
$$

where the standard electrode potential $E_{0}$ is defined as:

$$
E_{0}=-\Delta G=-(\Delta H-T \Delta S)
$$

The cell activation overpotential is expressed as (Barbir, 2005):

$$
\eta_{\text {act }}=\frac{R T}{\alpha F} \ln \left(\frac{I}{I_{0_{c}}}\right)
$$

where the cathode exchange current density $I_{0_{c}}$ is given by (Y. Wang, Chen, \& Cho, 2013):

$$
I_{0_{c}}=I_{0}^{r e f} \exp \left[\frac{-E_{a c t}}{R}\left(\frac{1}{T}-\frac{1}{353.15}\right)\right]
$$

The cell ohmic overpotential is expressed as (Barbir, 2005):

$$
\eta_{\text {Ohm }}=R_{\Omega} I
$$

$R_{\Omega}$ is the area specific resistance of the cell defined by: 


$$
R_{\Omega}=\int_{0}^{\delta_{M E M}} \frac{d x}{\sigma_{i}[\lambda(x)]}+\frac{2 \delta}{\sigma_{e}}+R_{B P}+R_{C}
$$

where the membrane ionic conductivity $\sigma_{i}$ which is a function of the membrane water content $\lambda$ is determined by (Springer, Zawodzinski, \& Gottesfeld, 1991):

$$
\sigma_{i}=(0.5139 \lambda-0.326) \exp \left(1268 \times\left(\frac{1}{303}-\frac{1}{T}\right)\right)
$$

the membrane water content is defined as (Springer et al., 1991):

$$
\lambda=\left\{\begin{array}{cc}
0.043+17.18 a-39.85 a^{2}+36 a^{3} & (0<a<1) \\
14+1.4(a-1) & (1 \leq a \leq 3)
\end{array}\right.
$$

where the activity of water vapour in the gas mixture a is calculated as (Springer et al., 1991):

$$
a=\frac{x_{W V} \times p_{g}}{p_{s a t}}
$$

the saturation pressure $p_{\text {sat }}$ is given by (Springer et al., 1991):

$$
\log p_{\text {sat }}=-2.1794+0.02953(T-273.15)-9.1837 \times 10^{-5}(T-273.15)^{2}+1.4454 \times 10^{-7}(T-273.15)^{3}
$$

The cell concentration overpotential is expressed as (O'Hayre, Cha, Colella, \& Prinz, 2006):

$$
\eta_{\text {con }}=c \ln \left(\frac{I_{L_{C}}}{I_{L_{c}}-I}\right)
$$

where the concentration constant $c$ and the cathode limiting current density $I_{L_{C}}$ are determined by (O'Hayre et al., 2006):

$$
\begin{gathered}
c=\frac{R T}{n F}\left(1+\frac{1}{\alpha}\right) \\
I_{L_{C}}=\frac{n F D C}{\delta}
\end{gathered}
$$

The species electrochemical mass flux is defined as:

$$
\dot{m}_{i}^{\prime \prime}= \pm \frac{I M_{i}}{n_{i} F}
$$

The capillary pressure of liquid water in the porous media is written as (Y. Wang et al., 2013):

$$
p_{c}=\sigma \cos \theta\left(\frac{\varepsilon}{K}\right)^{\frac{1}{2}} J(s)
$$

where $J(s)$ denotes Leverett function defined by (Y. Wang et al., 2013):

$$
J(s)=\left\{\begin{array}{c}
1.417(1-s)-2.120(1-s)^{2}+1.263(1-s)^{3} \quad \text { for } \theta<90^{\circ} \\
1.417 s-2.120 s^{2}+1.263 s^{3} \quad \text { for } \theta \geq 90^{\circ}
\end{array}\right.
$$

The effective diffusivity of the gas species $D_{g}^{e f f}$ is correlated with porosity and saturation (Nam \& Kaviany, 2003):

$$
D_{g}^{e f f}=D_{g} f(\varepsilon) g(s)
$$

where $f(\varepsilon)$ and $g(s)$ are the normalized porosity and saturation functions, calculated by (Dawes, Hanspal, Family, \& Turan, 2009):

$$
\begin{aligned}
& f(\varepsilon)=\frac{(\varepsilon-0.11)^{0.9}}{(1-0.11)^{0.9}} \\
& g(s)=\frac{((1-s)-0.11)^{0.9}}{(1-0.11)^{0.9}}
\end{aligned}
$$

The density of the two-phase mixture is defined by:

$$
\rho_{\text {mix }}=(1-s) \rho_{g}+s \rho_{l}
$$


The specific heat capacity of the two-phase mixture is defined by:

$$
c_{p_{\text {mix }}}=(1-s) c_{p_{g}}+s c_{p_{l}}
$$

The thermal conductivity of the two-phase mixture is defined by:

$$
k_{\text {mix }}=(1-s) k_{g}+s k_{l}
$$

The specific latent heat of evaporation or condensation of water is determined by (Nguyen \& White, 1993):

\subsection{Boundary Conditions}

$$
h_{m f g}=45070-41.9 \mathrm{~T}+3.44 \times 10^{-3} \mathrm{~T}^{2}+2.54 \times 10^{-6} \mathrm{~T}^{3}-8.98 \times 10^{-10} \mathrm{~T}^{4}
$$

Boundary conditions are applied at all the boundaries of the computational domain, as well as at the internal interfaces between the different components, as shown in Figure 3. Table 2 contains specified boundary and initial values used.

Dirichlet boundary conditions are applied at the fluid inlets meaning that the inlet values for velocity, temperature, and mass fractions are prescribed at the inlet of both the anode and the cathode gas flow channels. The inlet velocity is a function of the species stoichiometric flow ratio, the current density, the electrode active area, and the gas flow channel cross-section area. It is calculated according to (Liu, 2012):

$$
\left.U\right|_{\text {inlet }}=\xi \frac{I}{n F} A_{M E A} \frac{1}{x_{i}} \frac{R T}{p} \frac{1}{A_{c h}}
$$

The outlet value is prescribed for pressure at the outlet of both the anode and the cathode gas flow channels. Neumann boundary conditions are applied for all other variables, with their gradients assumed to be zero in the flow direction.

Insulation conditions are set for the flow of mass and chemical species at the interfaces between the fluids and the membrane as the latter is impermeable to the reactant gases.

Impermeability, no-slip and no-flux boundary conditions are applied at all solid-fluid interfaces within the computational domain. A zero-gradient temperature is applied at all the external surfaces of the cell.

For the transport of liquid water, the inlet value for liquid saturation is prescribed at the inlet of both the anode and cathode gas flow channels, and a zero-gradient liquid saturation is applied at the fluid outlets, as well as at all solid-fluid interfaces.

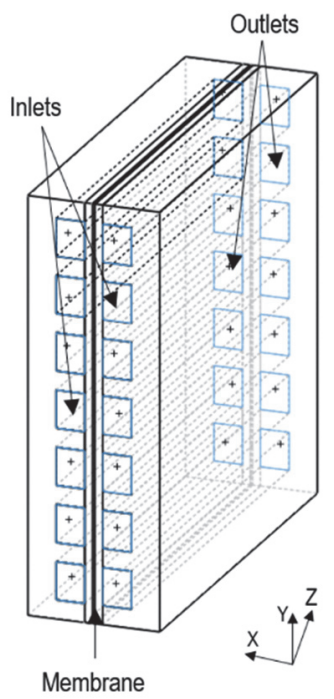

Figure 3. System boundaries 
Table 2. Boundary and initial values

\begin{tabular}{llllll}
\hline Equations & Anode inlet & Anode outlet & Cathode inlet & Cathode outlet & Walls \\
\hline Momentum & $U_{\text {fuel }}=0.8844 \mathrm{~m} \mathrm{~s}^{-1}$ & $p_{\text {fuel }}=101325 \mathrm{~Pa}$ & $U_{\text {air }}=2.4656 \mathrm{~m} \mathrm{~s}^{-}$ & $p_{\text {air }}=101325 \mathrm{~Pa}$ & $U=0$ \\
Species & $y_{\mathrm{H}_{2}}=0.2$ & $\nabla y_{\mathrm{H}_{2}}=0$ & $y_{\mathrm{O}_{2}}=0.2$ & $\nabla y_{\mathrm{O}_{2}}=0$ & $\nabla y=0$ \\
transport & $y_{\mathrm{H}_{2} \mathrm{O}}=0.8$ & $\nabla y_{\mathrm{H}_{2} \mathrm{O}}=0$ & $y_{\mathrm{H}_{2} \mathrm{O}}=0.15$ & $\nabla y_{\mathrm{H}_{2} \mathrm{O}}=0$ & \\
& & & $y_{\mathrm{N}_{2}}=0.65$ & $\nabla y_{\mathrm{N}_{2}}=0$ & \\
& & $\nabla T=0$ & $T=353 \mathrm{~K}$ & $\nabla T=0$ & $\nabla T=0$ \\
Energy & $T=353 \mathrm{~K}$ & $\nabla s=0$ & $s=0.2$ & $\nabla s=0$ & $\nabla s=0$ \\
Liquid & $S=0.2$ & & & & \\
water & & & & & \\
transport & & & & & \\
\hline
\end{tabular}

\section{Numerical Implementation}

\subsection{Solution Procedure}

Figure 4 illustrates the flow diagram of the solution algorithm. After the initialization phase, the program steps into the main loop where several calculations are repeated until convergence. For the galvanostatic (i.e. voltage calculation) run, the cell voltage is adjusted until the calculated mean current density is identical or very close to the initial value, whereas for the potentiostatic (i.e. current density calculation) simulation, the voltage is fixed.

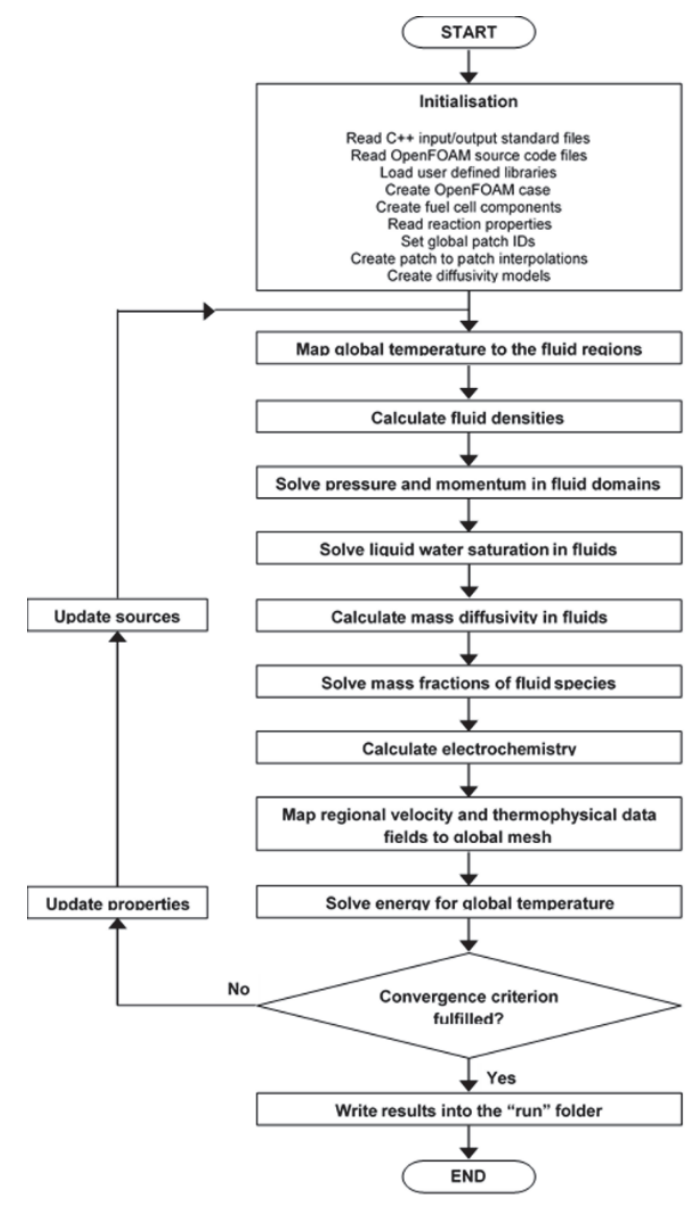

Figure 4. Flow diagram of the solution procedure

Table 3 contains the physical constants and properties at the cell operating temperature. Table 4 holds the electrochemical parameters and properties used. Table 5 summarises the case study operating conditions. 
Table 3. Physical constants and properties at 353K

\begin{tabular}{|c|c|c|c|}
\hline Parameter or property & Symbol & Value & Reference \\
\hline Density of air $\left(\mathrm{kg} \mathrm{m}^{-3}\right)$ & $\rho_{\text {air }}$ & 0.914 & $\begin{array}{l}\text { Calculated (Chang \& } \\
\text { Goldsby, 2014) }\end{array}$ \\
\hline Density of fuel $\left(\mathrm{kg} \mathrm{m}^{-3}\right)$ & $\rho_{\text {fuel }}$ & 0.2404 & $\begin{array}{l}\text { Calculated (Chang \& } \\
\text { Goldsby, 2014) }\end{array}$ \\
\hline Density of liquid water $\left(\mathrm{kg} \mathrm{m}^{-3}\right)$ & $\rho_{l}$ & 1000 & - \\
\hline Density of membrane $\left(\mathrm{kg} \mathrm{m}^{-3}\right)$ & $\rho_{M E M}$ & 1980 & $\begin{array}{l}\text { (Yuan, Tang, Pan, Li, } \\
\& \text { Tang, 2010) }\end{array}$ \\
\hline Density of bipolar plate $\left(\mathrm{kg} \mathrm{m}^{-3}\right)$ & $\rho_{B P}$ & 1880 & (Yuan et al., 2010) \\
\hline Heat capacity of air $\left(\mathrm{J} \mathrm{kg}^{-1} \mathrm{~K}^{-1}\right)$ & $c_{p, \text { air }}$ & 1108.85 & $\begin{array}{l}\text { Calculated (Todd \& } \\
\text { Young, 2002) }\end{array}$ \\
\hline Heat capacity of fuel $\left(\mathrm{J} \mathrm{kg}^{-1} \mathrm{~K}^{-1}\right)$ & $c_{p, f u e l}$ & 2062.74 & $\begin{array}{l}\text { Calculated (Todd \& } \\
\text { Young, 2002) }\end{array}$ \\
\hline Heat capacity of liquid water $\left(\mathrm{J} \mathrm{kg}^{-1} \mathrm{~K}^{-1}\right)$ & $c_{p, l}$ & 4190.0 & $\begin{array}{l}\text { (Gurau, Liu, \& Kakac, } \\
\text { 1998) }\end{array}$ \\
\hline Heat capacity of gas diffusion layer $\left(\mathrm{J} \mathrm{kg}^{-1} \mathrm{~K}^{-1}\right)$ & $c_{p, G D L}$ & 710 & (Yuan et al., 2010) \\
\hline Heat capacity of catalyst layer $\left(\mathrm{J} \mathrm{kg}^{-1} \mathrm{~K}^{-1}\right)$ & $c_{p, C L}$ & 710 & (Yuan et al., 2010) \\
\hline Heat capacity of membrane $\left(\mathrm{J} \mathrm{kg}^{-1} \mathrm{~K}^{-1}\right)$ & $c_{p, M E M}$ & 2000 & (Yuan et al., 2010) \\
\hline Heat capacity of bipolar plate $\left(\mathrm{J} \mathrm{kg}^{-1} \mathrm{~K}^{-1}\right)$ & $c_{p, B P}$ & 875 & (Yuan et al., 2010) \\
\hline Thermal conductivity of air $\left(\mathrm{W} \mathrm{m}^{-1} \mathrm{~K}^{-1}\right)$ & $k_{\text {air }}$ & 0.02867 & $\begin{array}{l}\text { Calculated (Poling et } \\
\text { al., 2000; Todd \& } \\
\text { Young, 2002) }\end{array}$ \\
\hline Thermal conductivity of fuel $\left(\mathrm{W} \mathrm{m}^{-1} \mathrm{~K}^{-1}\right)$ & $k_{\text {fuel }}$ & 0.08396 & $\begin{array}{l}\text { Calculated (Poling et } \\
\text { al., 2000; Todd \& } \\
\text { Young, 2002) }\end{array}$ \\
\hline Thermal conductivity of liquid water $\left(\mathrm{W} \mathrm{m}^{-1} \mathrm{~K}^{-1}\right)$ & $k_{l}$ & 0.6 & (Gurau et al., 1998) \\
\hline $\begin{array}{l}\text { Thermal conductivity of gas diffusion layer }\left(\mathrm{W} \mathrm{m}^{-1} \mathrm{~K}^{-}\right. \\
\left.{ }^{-}\right)\end{array}$ & $k_{G D L}$ & 1.6 & (Yuan et al., 2010) \\
\hline Thermal conductivity of catalyst layer $\left(\mathrm{W} \mathrm{m}^{-1} \mathrm{~K}^{-1}\right)$ & $k_{C L}$ & 8 & (Yuan et al., 2010) \\
\hline Thermal conductivity of membrane $\left(\mathrm{W} \mathrm{m}^{-1} \mathrm{~K}^{-1}\right)$ & $k_{M E M}$ & 0.67 & (Yuan et al., 2010) \\
\hline Thermal conductivity of bipolar plate $\left(\mathrm{W} \mathrm{m}^{-1} \mathrm{~K}^{-1}\right)$ & $k_{B P}$ & 10.7 & (Yuan et al., 2010) \\
\hline Electronic conductivity of gas diffusion layer $\left(\mathrm{S} \mathrm{m}^{-1}\right)$ & $\sigma_{e, G D L}$ & 5000 & (Yuan et al., 2010) \\
\hline Electronic conductivity of catalyst layer $\left(\mathrm{S} \mathrm{m}^{-1}\right)$ & $\sigma_{e, C L}$ & 1000 & (Yuan et al., 2010) \\
\hline Electronic conductivity of bipolar plate $\left(\mathrm{S} \mathrm{m}^{-1}\right)$ & $\sigma_{e, B P}$ & $8.3 \times 10^{4}$ & (Yuan et al., 2010) \\
\hline Dynamic viscosity of air (Pa s) & $\mu_{\text {air }}$ & $1.5158 \times 10^{-5}$ & $\begin{array}{l}\text { Calculated (Poling et } \\
\text { al., 2000; Todd \& } \\
\text { Young, 2002; Yaws, } \\
\text { 2012) }\end{array}$ \\
\hline Dynamic viscosity of fuel (Pa s) & $\mu_{\text {fuel }}$ & $1.5 \times 10^{-5}$ & $\begin{array}{l}\text { Calculated (Poling et } \\
\text { al., 2000; Todd \& } \\
\text { Young, 2002; Yaws, } \\
\text { 2012) }\end{array}$ \\
\hline
\end{tabular}


Table 4. Electrochemical parameters and properties

\begin{tabular}{llll}
\hline Parameter or property & Symbol & Value & Reference \\
\hline Cathode charge transfer coefficient & $\alpha_{c}$ & 1.0 & - \\
Cathode activation energy $\left(\mathrm{J} \mathrm{mol}^{-1}\right)$ & $E_{a c t, c}$ & 73220.0 & $\begin{array}{l}\text { (Parthasarathy, } \\
\text { Dave, } \\
\text { Srinivasan, }\end{array}$ \\
& & & $\begin{array}{l}\text { Appleby, \& } \\
\text { Martin, 1992) }\end{array}$ \\
Reference exchange current density $\left(\mathrm{A} \mathrm{m}^{-2}\right)$ & & & (Parthasarathy \\
& & & et al., 1992) \\
Enthalpy of formation of water vapour $\left(\mathrm{J} \mathrm{mol}^{-1}\right)$ & $I_{0}^{\text {ref }}$ & 0.0139 & (Yaws, 2009) \\
Standard entropy of hydrogen $\left(\mathrm{J} \mathrm{mol}^{-1} \mathrm{~K}^{-1}\right)$ & $\Delta_{H_{2} O}$ & $-241.826 \times 10^{3}$ & (Yaws, 2009) \\
Standard entropy of oxygen $\left(\mathrm{J} \mathrm{mol}^{-1} \mathrm{~K}^{-1}\right)$ & $S_{\mathrm{H}_{2}}$ & 130.68 & (Yaws, 2009) \\
Standard entropy of nitrogen $\left(\mathrm{J} \mathrm{mol}^{-1} \mathrm{~K}^{-1}\right)$ & $S_{O_{2}}$ & 205.152 & (Yaws, 2009) \\
Standard entropy of water vapour $\left(\mathrm{J} \mathrm{mol}^{-1} \mathrm{~K}^{-1}\right)$ & $S_{N_{2}}$ & 191.609 & (Yaws, 2009) \\
\hline
\end{tabular}

Table 5. Case study operating conditions

\begin{tabular}{|c|c|c|c|}
\hline Variable & Symbol & Value & Reference \\
\hline Cell voltage (V) & V & 0.6 & - \\
\hline Cell temperature $(\mathrm{K})$ & $T_{\text {cell }}$ & 353 & - \\
\hline Cathode fluid pressure $(\mathrm{Pa})$ & $P_{\text {cathodeFluid }}$ & 101325 & - \\
\hline Anode fluid pressure $(\mathrm{Pa})$ & $p_{\text {anodeFluid }}$ & 101325 & - \\
\hline Cathode fluid velocity $\left(\mathrm{m} \mathrm{s}^{-1}\right)$ & $U_{\text {cathodeFluid }}$ & 2.4656 & $\begin{array}{l}\text { Calculated (Liu, } \\
\text { 2012) }\end{array}$ \\
\hline Anode fluid velocity $\left(\mathrm{m} \mathrm{s}^{-1}\right)$ & $U_{\text {anodeFluid }}$ & 0.8844 & $\begin{array}{l}\text { Calculated (Liu, } \\
\text { 2012) }\end{array}$ \\
\hline $\mathrm{O}_{2}$ diffusivity in air mixture $\left(\mathrm{m}^{2} \mathrm{~s}^{-1}\right)$ & $D_{O_{2}, a i r}$ & $2.939 \times 10^{-5}$ & $\begin{array}{l}\text { Calculated } \\
\text { (Fairbanks \& Wilke, } \\
\text { 1950; Fuller, Ensley, } \\
\text { \& Giddings, 1969; } \\
\text { Fuller et al., 1966) }\end{array}$ \\
\hline Effective $\mathrm{O}_{2}$ diffusivity in gas diffusion layer $\left(\mathrm{m}^{2} \mathrm{~s}^{-1}\right)$ & $D_{O_{2}, G D L}^{e f f}$ & $9.732 \times 10^{-6}$ & $\begin{array}{l}\text { Calculated } \\
\text { (Fairbanks \& Wilke, } \\
\text { 1950; Fuller et al., } \\
\text { 1969; Fuller et al., } \\
\text { 1966; Geankoplis, } \\
\text { 1993; Welty et al., } \\
\text { c2008) }\end{array}$ \\
\hline Effective $\mathrm{O}_{2}$ diffusivity in catalyst layer $\left(\mathrm{m}^{2} \mathrm{~s}^{-1}\right)$ & $D_{O_{2}, C L}^{e f f}$ & $7.785 \times 10^{-6}$ & $\begin{array}{l}\text { Calculated } \\
\text { (Fairbanks \& Wilke, } \\
\text { 1950; Fuller et al., } \\
\text { 1969; Fuller et al., } \\
\text { 1966; Geankoplis, } \\
\text { 1993; Welty et al., } \\
\text { c2008) }\end{array}$ \\
\hline $\mathrm{H}_{2}$ diffusivity in fuel mixture $\left(\mathrm{m}^{2} \mathrm{~s}^{-1}\right)$ & $D_{H_{2}, \text { fuel }}$ & $0.122 \times 10^{-3}$ & $\begin{array}{l}\text { Calculated } \\
\text { (Fairbanks \& Wilke, } \\
\text { 1950; Fuller et al., } \\
\text { 1969; Fuller et al., }\end{array}$ \\
\hline
\end{tabular}




\begin{tabular}{|c|c|c|c|}
\hline & & & 1966) \\
\hline Effective $\mathrm{H}_{2}$ diffusivity in gas diffusion layer $\left(\mathrm{m}^{2} \mathrm{~s}^{-1}\right)$ & $D_{H_{2}, G D L}^{e f f}$ & $4.031 \times 10^{-5}$ & $\begin{array}{l}\text { Calculated } \\
\text { (Fairbanks \& Wilke, } \\
\text { 1950; Fuller et al., } \\
\text { 1969; Fuller et al., } \\
\text { 1966; Geankoplis, } \\
\text { 1993; Welty et al., } \\
\text { c2008) }\end{array}$ \\
\hline Effective $\mathrm{H}_{2}$ diffusivity in catalyst layer $\left(\mathrm{m}^{2} \mathrm{~s}^{-1}\right)$ & $D_{H_{2}, C L}^{e f f}$ & $1.252 \times 10^{-5}$ & $\begin{array}{l}\text { Calculated } \\
\text { (Fairbanks \& Wilke, } \\
\text { 1950; Fuller et al., } \\
\text { 1969; Fuller et al., } \\
\text { 1966; Geankoplis, } \\
\text { 1993; Welty et al., } \\
\text { c2008) }\end{array}$ \\
\hline Anode liquid water saturation & $s$ & 0.2 & - \\
\hline Cathode liquid water saturation & $s$ & 0.2 & - \\
\hline Mass fraction of $\mathrm{O}_{2}$ & $y_{\mathrm{O}_{2}}$ & 0.2 & - \\
\hline Mass fraction of air $\mathrm{H}_{2} \mathrm{O}$ & $y_{\mathrm{H}_{2} \mathrm{O}}$ & 0.15 & - \\
\hline Mass fraction of $\mathrm{N}_{2}$ & $y_{N_{2}}$ & 0.65 & - \\
\hline Mass fraction of $\mathrm{H}_{2}$ & $y_{\mathrm{H}_{2}}$ & 0.2 & - \\
\hline Fraction of fuel $\mathrm{H}_{2} \mathrm{O}$ & $y_{\mathrm{H}_{2} \mathrm{O}}$ & 0.8 & - \\
\hline Stoichiometry ratio - cathode air & $\xi_{\text {air }}$ & 2.0 & - \\
\hline Stoichiometry ratio - anode fuel & $\xi_{\text {fuel }}$ & 1.5 & - \\
\hline
\end{tabular}

\subsection{Overview of the Toolbox}

The work presented in this paper extends the 3-D, non-isothermal, and single-phase flow model for a PEM fuel cell previously introduced (Kone et al., 2017a), to include liquid water formation, transport, and their effects in the fuel cell. The toolbox developed follows the same structure and organisation as OpenFOAM, as shown in Figure 5. One limitation of the OpenFOAM platform is that it has no multiphase flow PEM fuel cell module. The present tool in this study actively include the multi-phase flow programme. The software has two major components: pemfcMultiphaseNonIsothermalSolver and run (see Figure 5). The pemfcMultiphaseNonIsothermalSolver directory contains the source code for the solvers and libraries, whereas the run directory stores the constructed simulation case files. 


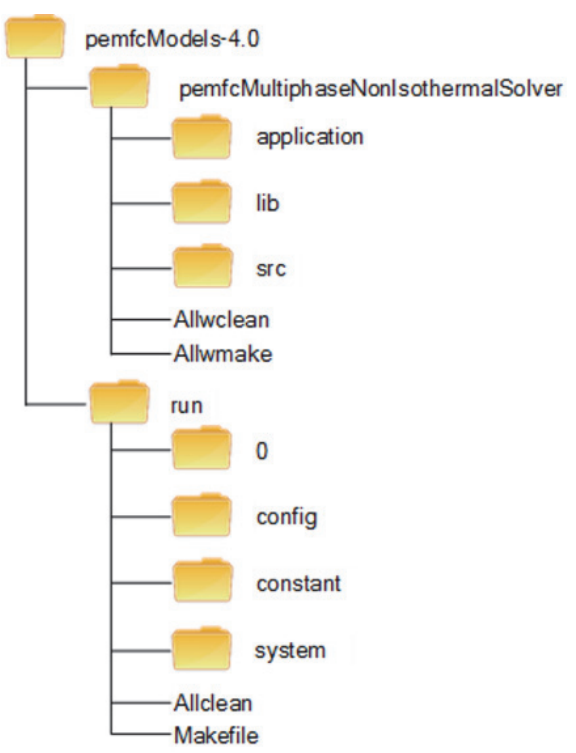

Figure 5. File structure of the toolbox

A pemfcMultiphaseNonIsothermalSolver.c file that includes the main loop of the program is stored in the applications sub-directory. The files for the necessary libraries to link to during runtime are stored and compiled in the lib sub-directory. These include classes for geometry and mesh manipulation, multicomponent gas diffusivities, etc. The $\operatorname{src}$ sub-directory stores various program files which contains specific instructions for the initialization, as well as algorithms for solving the different field variables. The 0 sub-directory is a time subdirectory that holds the initial field data files. The config sub-directory stores the data files for geometry construction and mesh creation. The constant sub-directory contains information files on mesh and boundary conditions, along with physical properties. The system sub-directory stores the control files for the solvers, schemes, and solutions.

\section{Validation}

\subsection{Grid Refinement Study}

A mesh independence study was carried out to investigate the dependency of the results of the model on the mesh. Thus, the grid that was used for the case study was refined twice by adding $20 \%$ of the cells and $40 \%$ of the cells in every direction. Computations at case study conditions were then performed on these refined meshes and the temperature field solutions were compared with each other. The computation results are shown in Table 6 . The maximum difference of temperature solution is $0.08 \%$ for the compared meshes, indicating that the case study mesh (Mesh 1) provides sufficient confidence.

Table 6. Mesh independence

\begin{tabular}{llll}
\hline & Mesh 1 & Mesh 2 & Mesh 3 \\
\hline Total number of cells & 134552 & 224432 & 351000 \\
Global temperature (K) & $\mathrm{T}_{\min }=353.3$ & $\mathrm{~T}_{\min }=353.2$ & $\mathrm{~T}_{\min }=353.2$ \\
& $\mathrm{~T}_{\text {ave }}=362.4$ & $\mathrm{~T}_{\text {ave }}=362.6$ & $\mathrm{~T}_{\text {ave }}=362.5$ \\
& $\mathrm{~T}_{\max }=365.3$ & $\mathrm{~T}_{\max }=365.6$ & $\mathrm{~T}_{\max }=365.5$ \\
\hline
\end{tabular}

\subsection{Comparison with Literature Model Results and Experimental Data}

Figure 6 compares the cell polarization or I-V curve obtained using the concentration constant values of $0.2,0.25$ and 0.3 at case study conditions, to those of the numerical model and experimental data reported by (Yuan et al., 2010). This is because some of the parameters and properties used in the present model were directly borrowed from the model in (Yuan et al., 2010). In addition, other parameters such as the transfer coefficient, the reference exchange current density, etc. were adjusted to achieve a good agreement between the compared models. 
From Figure 6, it is shown that the compared polarization curves follow similar trends, confirming the validity of the present model. The difference between the I-V curves at high current densities can be attributed to, amongst other factors, the combined effects of the cell inlet flow rates, the cell design details and material properties, and the concentration losses. In fact, the effective value of the concentration constant seen in real fuel cell operation is often much larger than the theoretical value. Therefore, in many modelling work, this constant is obtained empirically (O'Hayre et al., 2006).

Based on the present comparison, it is clear that the choice of the value for the concentration constant is decisive in obtaining a good agreement between the results of the present work and the numerical and experimental results at high densities from a previous study (Yuan et al., 2010). A $c$ value of 0.3 provides the best agreement between the results.

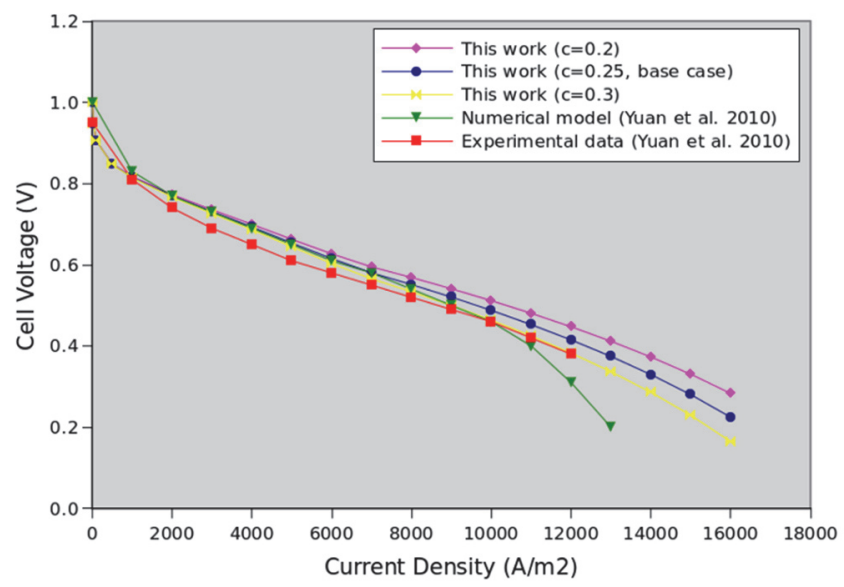

Figure 6. Cell I-V curves compared to the numerical and experimental results from a previous study (Yuan et al., 2010)

At low current densities, increasing the value of $c$ has negligible effects on the cell potential, whereas at the current densities higher than $4000 \mathrm{~A} / \mathrm{m}^{2}$, the effects get significant and results in decreased cell potential.

Figure 7 compares the activation, ohmic, and concentration overpotentials. The values for the concentration constant used above were carefully selected to ensure realistic proportions among these three types of overpotentials in the fuel cell. The activation overpotential constitutes the largest potential loss at any current density because of slow reaction rates at the electrodes. The potential loss associated with the ohmic resistance become significant at moderate current densities due to resistance to the flow of electrons and protons. The potential loss caused by mass transport rises at high current densities as the electrodes are rapidly depleted of the reactants by the electrochemical reactions.

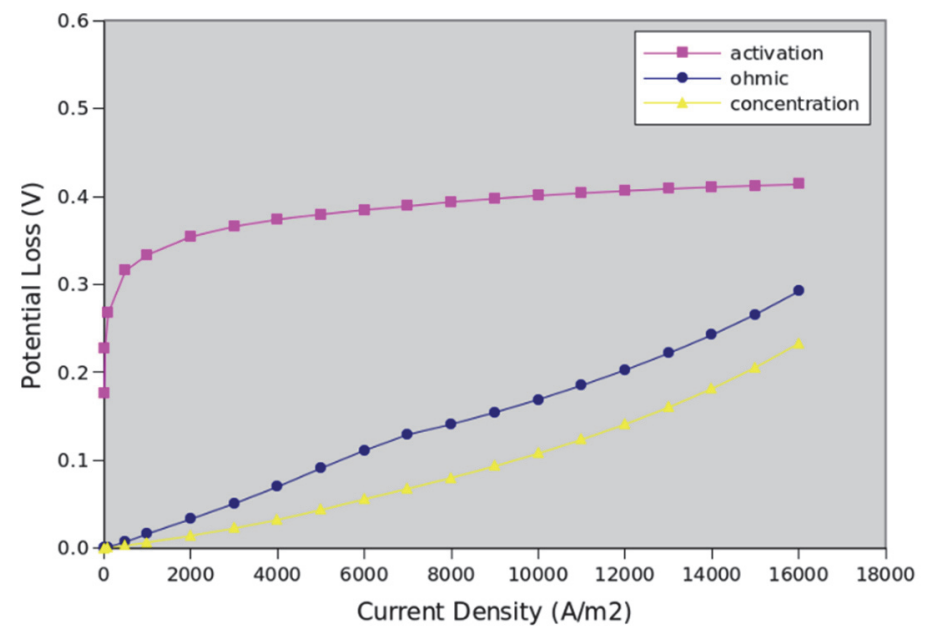

Figure 7. Cell potential losses at case study conditions with $\mathrm{c}=0.25$ 


\section{Discussion of the Case Study Results}

The post-processing and the visualization of the results were achieved using ParaView, which is an open-source code visualization software that is used for postprocessing in OpenFOAM through the paraFoam utility, supplied with OpenFOAM.

Figure 8 (a) and (b) display the velocity profiles along the gas flow channels for the fuel and air, respectively. The highest velocity is observed at the centre lines of the channels at the cell outlet while the lowest velocity is seen at the walls. These contours agree with those of fully developed laminar flow.
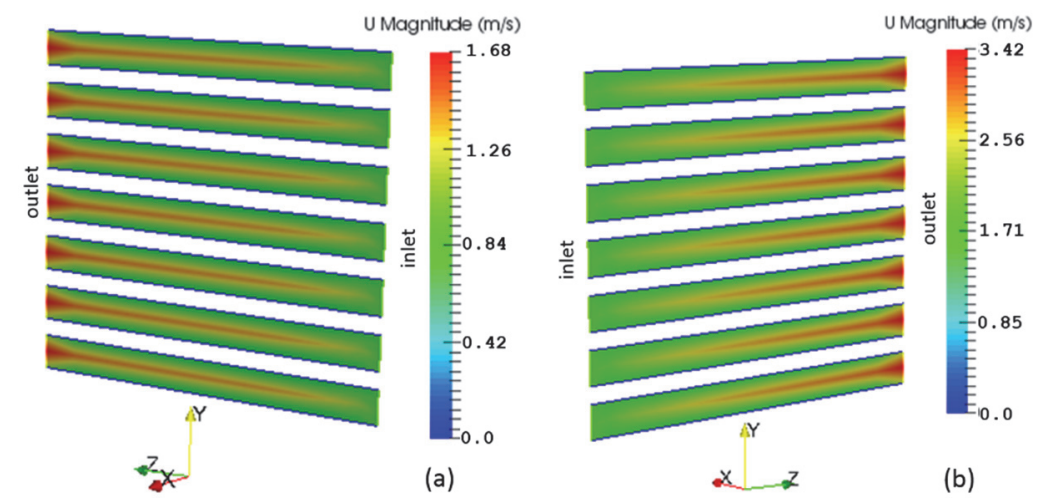

Figure 8. Velocity profiles along the gas flow channels (a) Fuel; (b) Air

Figure 9 (a) and (b) illustrate the distribution of pressure in the fuel and air side gas flow channels, respectively. The increase in the fluid velocity at the cell outlet as seen in Figure 10 and 11, results in a decrease in the fluid pressure at this location.

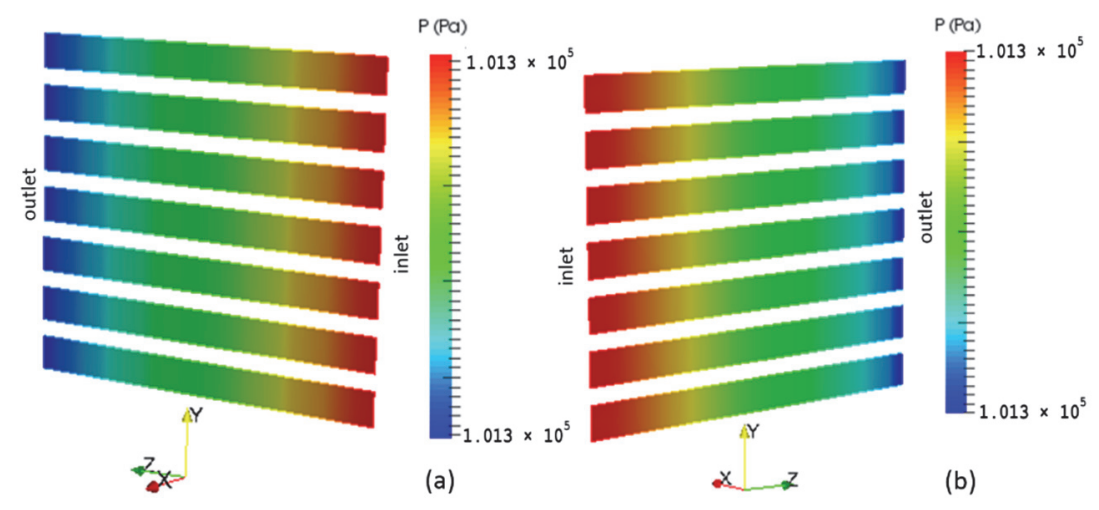

Figure 9. Pressure distribution in the gas flow channels (a) Fuel; (b) Air 


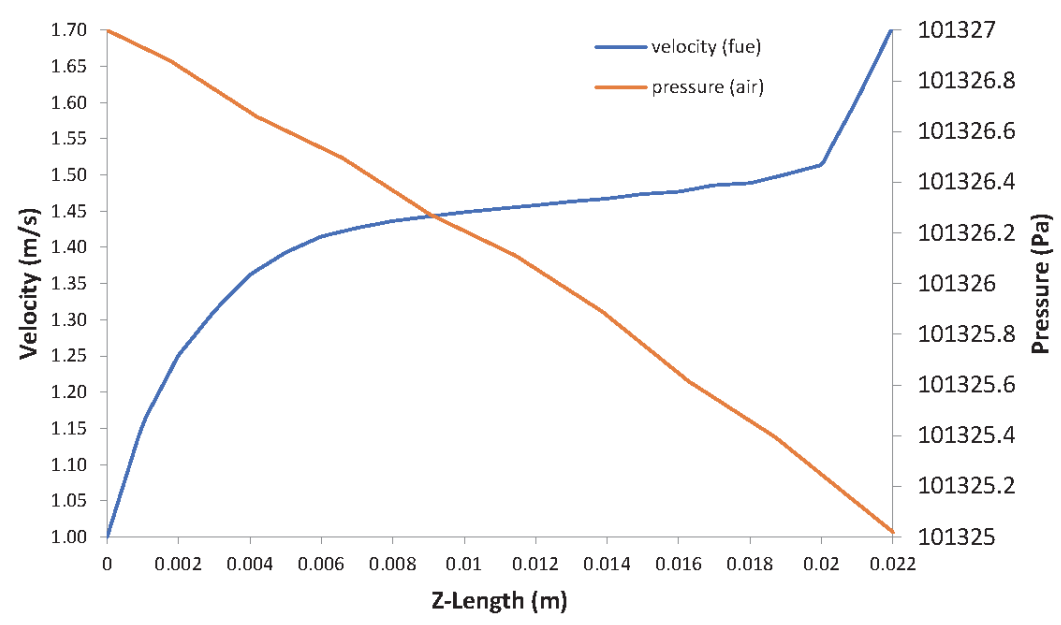

Figure 10. Velocity vs pressure - fuel

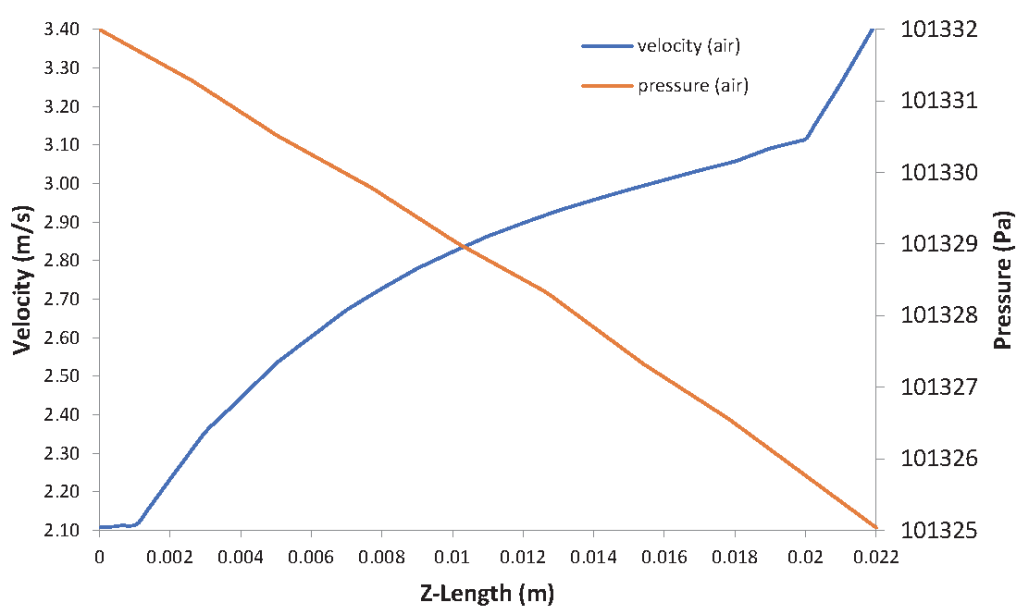

Figure 11. Velocity vs pressure - air

Figure 12 and 13 represent the distribution of liquid water saturation in the anode and the cathode, respectively. Water in a PEM fuel cell originates from water vapour in humid reactant gases and the oxygen reduction reaction (in the present work, it is assumed that the product water is in vapour form). Water vapour condensates into liquid water when its partial pressure is higher than the saturation pressure which is greatly affected by the local temperature. Therefore, liquid water in the fuel cell results from water vapour condensation. From Figure 12 and 13 , it is observed that the saturation of liquid water increases from the cell inlet to the cell outlet. The reason why saturation swells along the flow direction is twofold: increased water vapour partial pressure along the flow direction because of the build-up of water vapour, and the nature of liquid water flow. 


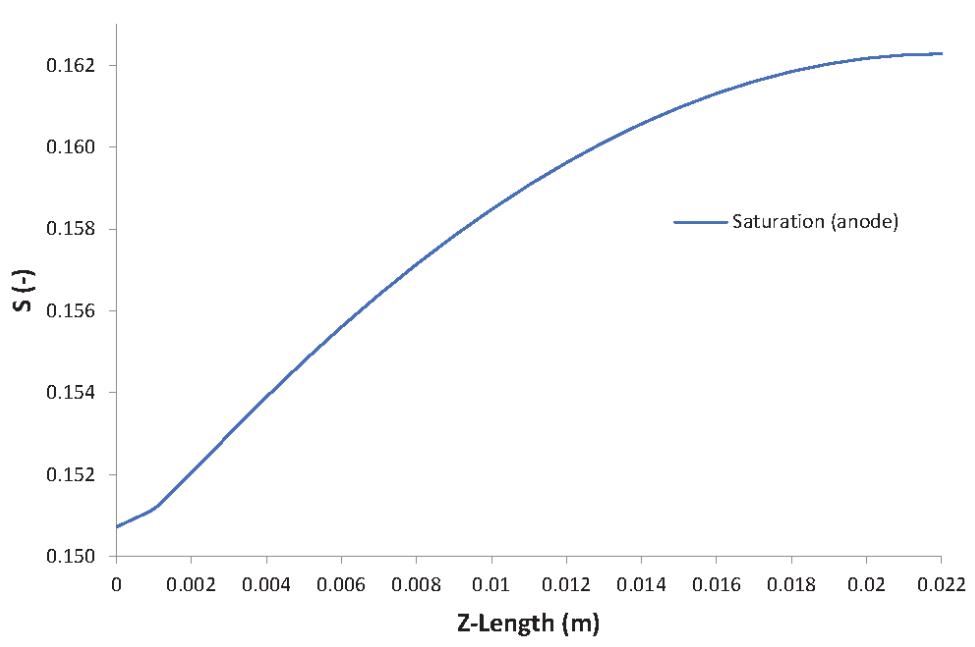

Figure 12. Liquid water saturation in the anode side

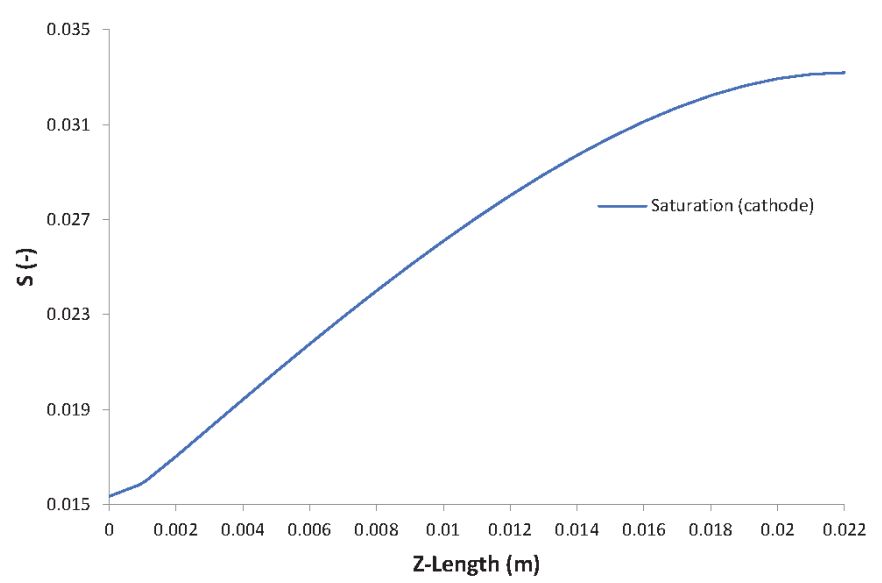

Figure 13. Liquid water saturation in the cathode side

Figure 14 (a) and (b) show the distribution of hydrogen and oxygen mass fractions, respectively. As the reactants are consumed during the electrochemical reactions, their mass fractions decrease from the cell inlet to the cell outlet, and from the gas flow channels to the catalyst layer. The concentration of reactant gases in the electrodes is directly proportional to pressure (see Figure 15 and 16). It is also noticed that, compared to the results of the singlephase flow model reported in (Kone et al., 2017a), the mass fractions of the reactant gases have further decreased in the multiphase flow case because the transport of the gas species is hindered by the presence of liquid water (see Figure 17 and 18). In addition, the clogging of the diffusion passages by water droplets results in reduced diffusion rates.
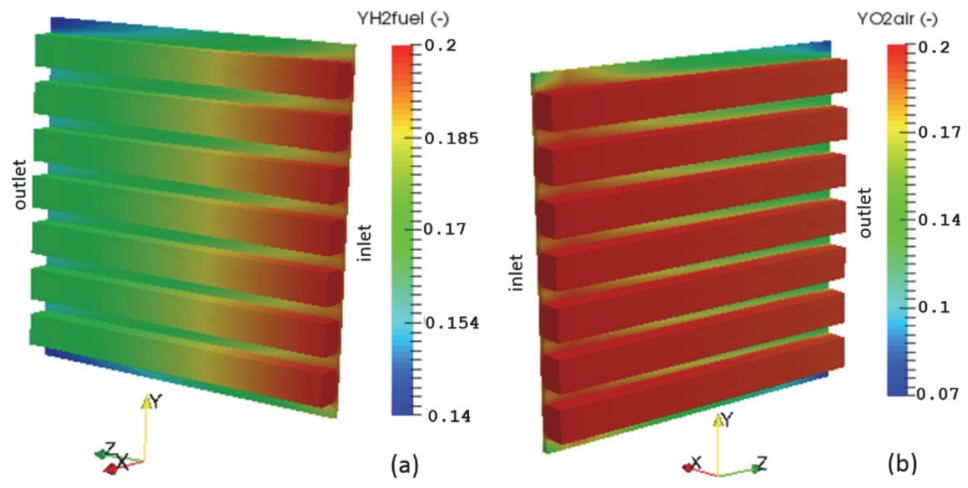

Figure 14. Species mass fraction distribution (a) Hydrogen; (b) Oxygen 


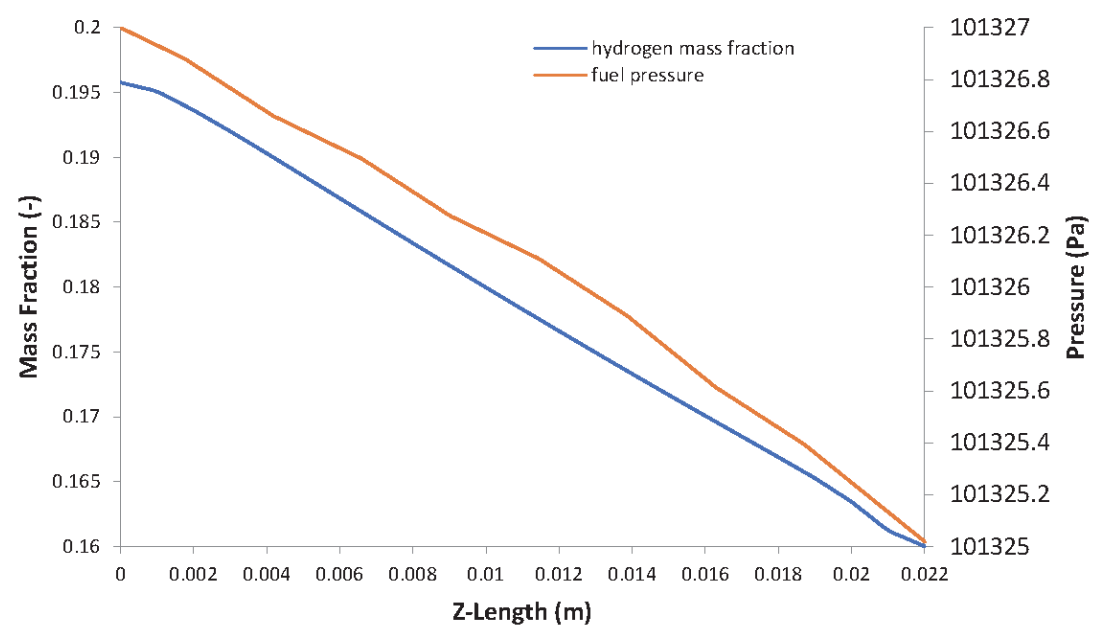

Figure 15. Hydrogen mass fraction vs fuel pressure

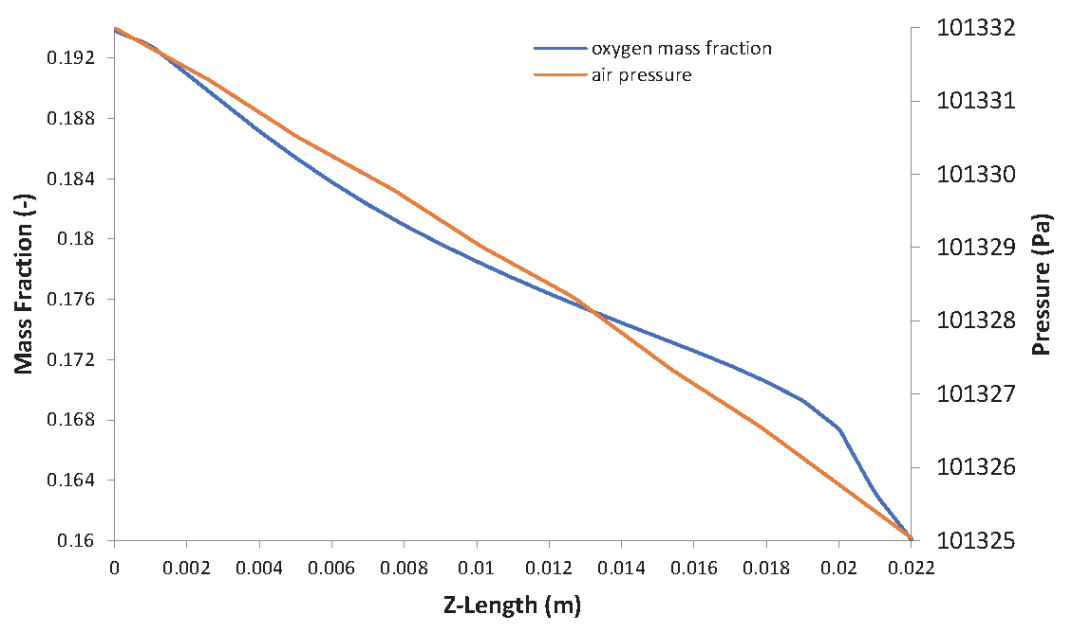

Figure 16. Oxygen mass fraction vs air pressure

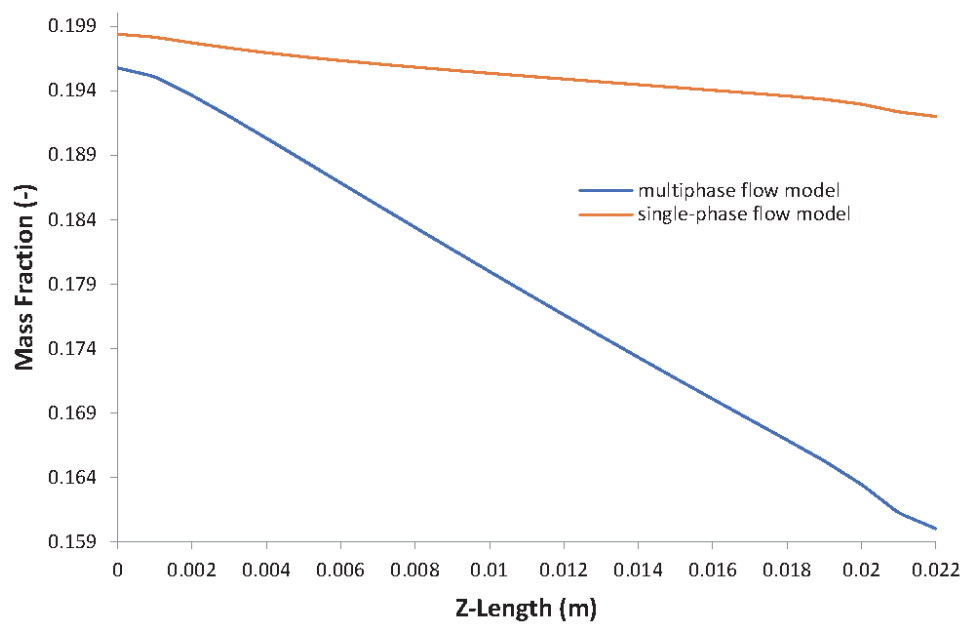

Figure 17. Comparison with the single-phase flow model in (Kone et al., 2017a) - hydrogen mass fraction 


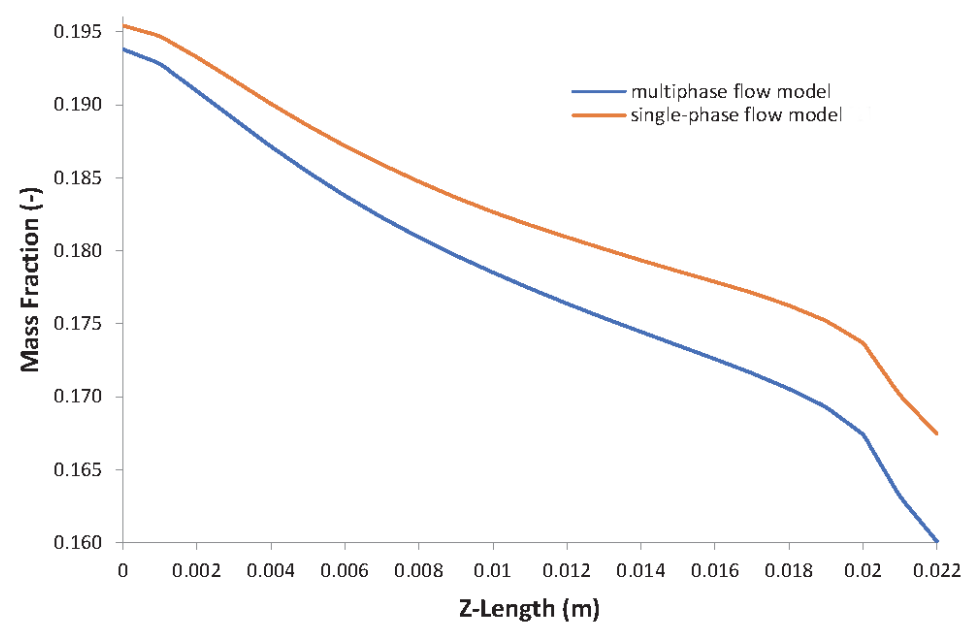

Figure 18. Comparison with the single-phase flow model in (Kone et al., 2017a) - oxygen mass fraction

Figure 19 (a) illustrates the Nernst potential decreasing from the cell inlet to the cell outlet as the anode is depleted of hydrogen because of the combined effects of hydrogen consumption and water vapour production by the electrochemical reactions. Figure 19 (b) shows the distribution of the observed local current density. It decreases in the flow direction because of the reduction in the Nernst potential in the same direction. A significant reduction is noticed at the corner edges of the outlet since these areas are devoid of active reaction surface. Compared to results of the single-phase flow model reported in (Kone et al., 2017a), a further reduction in both the Nernst potential and the local current density is noticed (see Figure 20 and 21, respectively). This can be attributed to a reduced effective reaction surface area caused by the presence of water droplets. Figure 19 (c) displays the local temperature distribution. This is affected by ohmic heating, and the heat generated during the electrochemical reactions and water phase change. The additional heat released by water phase change results in a significant increase in the average local temperature, in comparison with the average local temperature obtained with the single-phase flow model (Kone et al., 2017a) (see Figure 22).

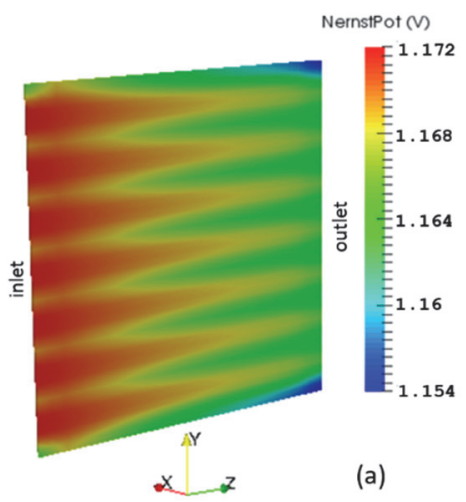

(a)
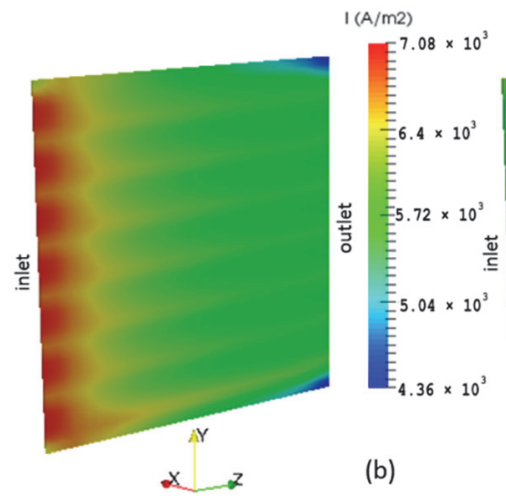

(b)

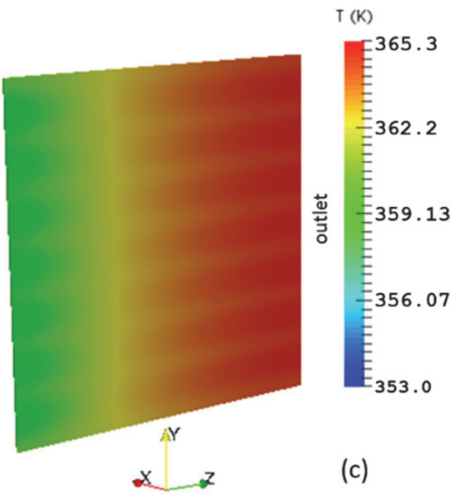

(c)

Figure 19. Membrane-cathode interface showing the distribution of (a) Nernst potential; (b) Local current density; (c) Temperature 


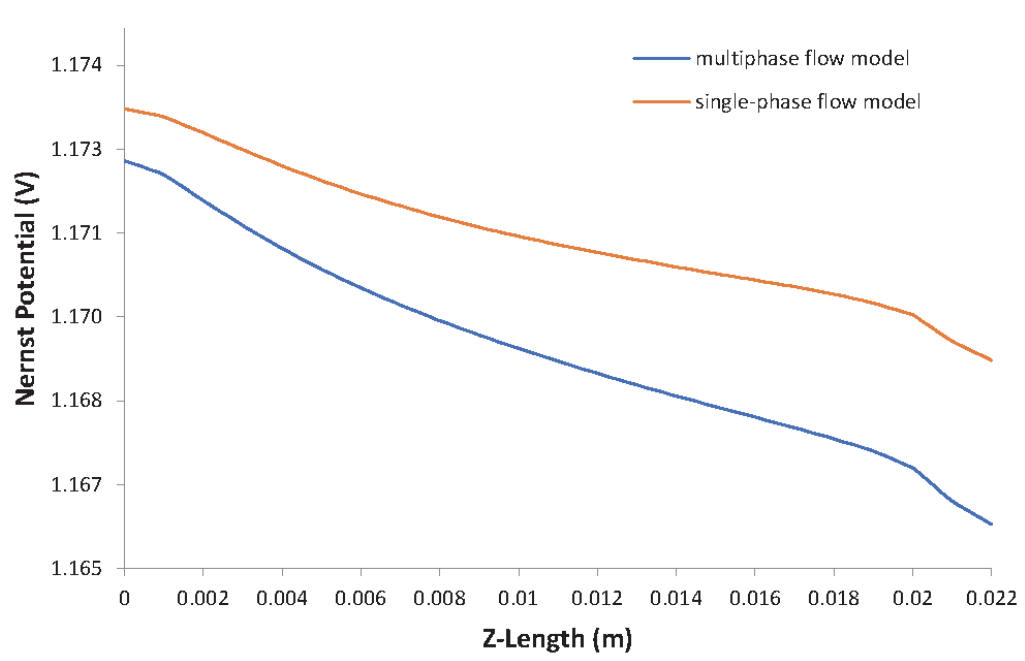

Figure 20. Comparison with the single-phase flow model in (Kone et al., 2017a) - Nernst potential

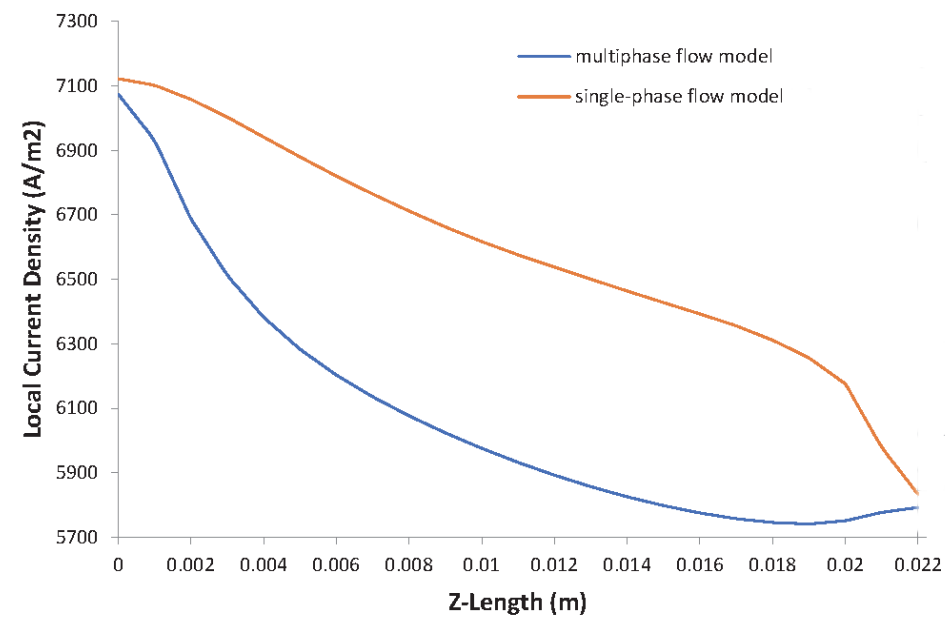

Figure 21. Comparison with the single-phase flow model in (Kone et al., 2017a) - current density

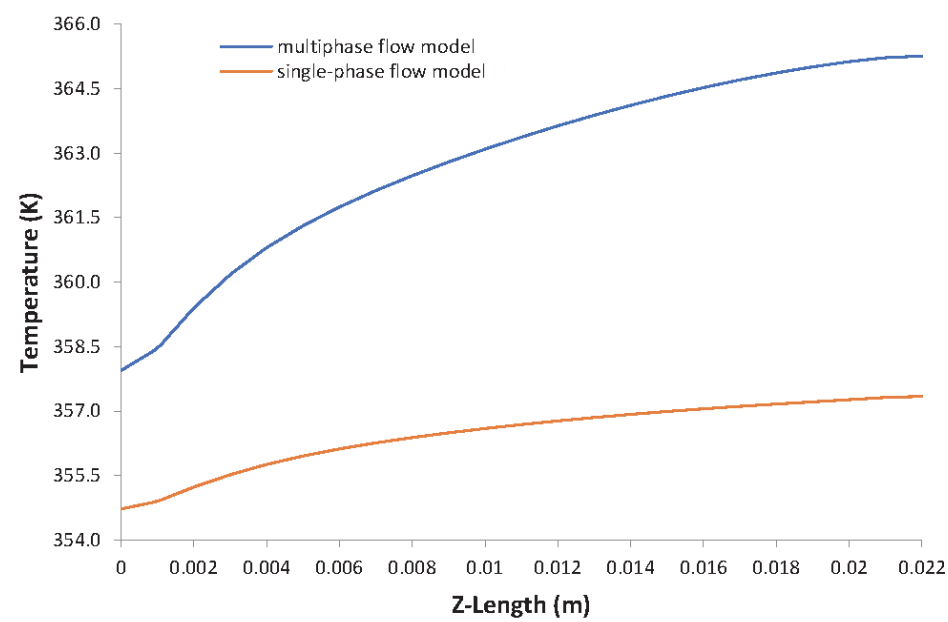

Figure 22. Comparison with the single-phase flow model in (Kone et al., 2017a) - temperature

Figure 23 compares the case study polarization curves of the present multiphase flow model and the single-phase flow model in past work (Kone et al., 2017a). The difference between the two lines is not significant at low current densities. At moderate and high current densities, however, the gap between the two lines starts to widen. For an 
identical current density, the cell potential is lower with the multiphase flow model than that with the single-phase flow model. This is because the multiphase flow model accounts for liquid water effects on the gaseous reactant transport, which causes higher concentration losses. On the other hand, the single-phase flow model cannot accurately predict the cell potential drop when the local current density draws closer to the limiting current density.

In other words, while the existence of liquid water has beneficial effects in terms of membrane hydration, it also blocks the gas diffusion passages, reduces the diffusion rate and the effective reaction surface area, and hence leads to a deterioration in fuel cell performance.

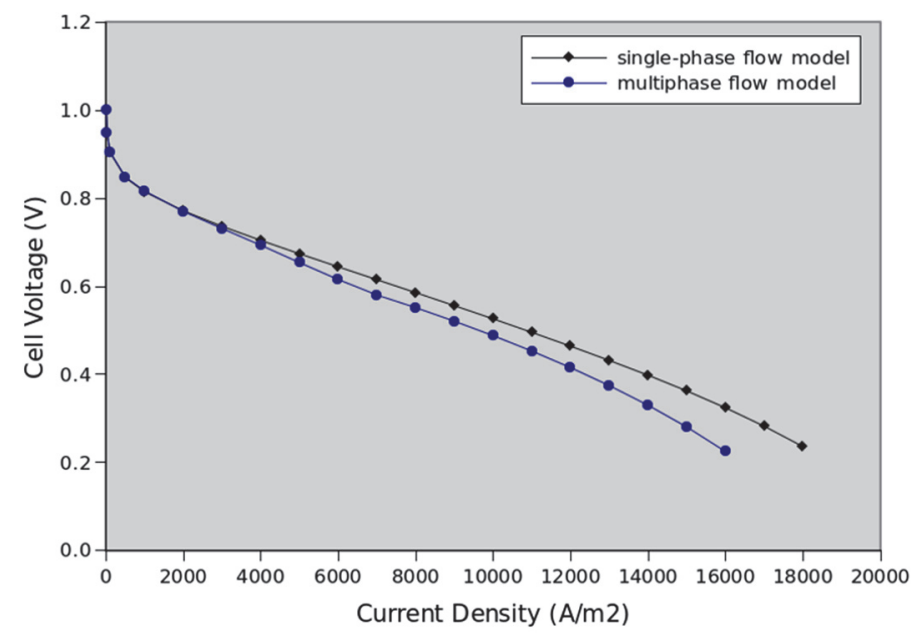

Figure 23. Comparison of the cell polarization curve with the single-phase flow model curve in (Kone et al., 2017a)

\section{Conclusion and Outlook}

An open-source code toolbox for the numerical simulation of multiphase flow in a PEM fuel cell has been developed using OpenFOAM. The toolbox includes a main program, relevant library classes, and a constructed simulation case for a co-flow galvanostatic simulation. The mathematical model accounts for liquid water formation, transport, and their effects in the fuel cell.

The case study results are as expected. Detailed distributions of velocity, pressure, liquid water saturation, the species mass fractions, Nernst potential, local current density and temperature fields were presented. The results of a mesh independence study revealed that for the coarsest case study mesh, the solution proved to be grid independent. The cell polarization curve obtained with the case study conditions was plotted and compared to a single-phase flow model polarization curve and the polarization curves from a known literature model and experimental data. The comparison with the single-phase flow model confirms that the existence of liquid water in the system reduces the cell performance. The result shows a good agreement when compared with numerically and experimentally obtained data. Furthermore, the outcomes of a parametric study showed the key role played by the concentration constant in shaping the cell polarization curve.

The developed model can, by no means, be considered complete. The present study can still be improved. So far, the membrane water transport (e.g. dissolved water transport) has been simplified. Also, to facilitate numerical implementation, it was assumed that the electrochemical reactions occur at a single interface between the cathode catalyst layer and the membrane. The developed toolbox can therefore be extended to include other features, such as improved membrane and or catalyst models.

\section{Acknowledgments}

The authors acknowledge the financial support from the International Doctoral Innovation Centre, Ningbo Education Bureau, Ningbo Science and Technology Bureau, and the University of Nottingham. This work was also supported by the UK Engineering and Physical Sciences Research Council [grant numbers EP/G037345/1 and EP/L016362/1], Faculty of Science and Engineering at University of Nottingham Ningbo China [SRG code 01.03.05.04.2015.02.001], Ningbo Natural Science Foundation Program [project code 2013A610107], Zhejiang Natural Science Foundation [project code LY18E060004] and Ningbo Science and Technology Bureau's Technology Innovation Team [Grant No. 2016B10010]. 


\section{References}

Ashrafi, M., \& Shams, M. (2017). The effects of flow-field orientation on water management in PEM fuel cells with serpentine channels. Applied Energy, 208, 1083-1096. https://doi.org/10.1016/j.apenergy.2017.09.044

Barbir, F. (2005). PEM fuel cells: theory and practice. Amsterdam ; London: Elsevier Academic.

Barreras, F., Lozano, A., Valino, L., Mustafa, R., \& Marin, C. (2008). Fluid dynamics performance of different bipolar plates - Part I. Velocity and pressure fields. Journal of Power Sources, 175(2), 841-850. https://doi.org/10.1016/j.jpowsour.2007.09.107

Beale, S. B., Choi, H. W., Pharoah, J. G., Roth, H. K., Jasak, H., \& Jeon, D. H. (2016). Open-source computational model of a solid oxide fuel cell. Computer Physics Communications, 200, 15-26. https://doi.org/10.1016/j.cpc.2015.10.007

Chang, R., \& Goldsby, K. A. (2014). General Chemistry: The Essential Concepts. New York: McGraw-Hill.

Dawes, J. E., Hanspal, N. S., Family, O. A., \& Turan, A. (2009). Three-dimensional CFD modelling of PEM fuel cells: An investigation into the effects of water flooding. Chemical Engineering Science, 64(12), 2781-2794. https://doi.org/10.1016/j.ces.2009.01.060

Fairbanks, D. F., \& Wilke, C. R. (1950). Diffusion coefficients in multicomponent gas mixtures. Industrial and Engineering Chemistry, 42(3), 471-475. https://doi.org/10.1021/ie50483a022

Ferreira, R. B., Falcao, D. S., Oliveira, V. B., \& Pinto, A. (2015). Numerical simulations of two-phase flow in proton exchange membrane fuel cells using the volume of fluid method - A review. Journal of Power Sources, 277, 329-342. https://doi.org/10.1016/j.jpowsour.2014.11.124

Fuller, E. N., Ensley, K., \& Giddings, J. C. (1969). Diffusion of halogenated hydrocarbons in helium . effect of structure on collision cross sections. Journal of Physical Chemistry, 73(11), 3679-3685. https://doi.org/10.1021/j100845a020

Fuller, E. N., Schettle, P. D., \& Giddings, J. C. (1966). A new method for prediction of binary gas-phase diffusion coeffecients. Industrial and Engineering Chemistry, 58(5), 19-27.

Geankoplis, C. J. (1993). Transport processes and Unit Operations (3rd ed.). New Jersey: Prentice-Hall.

Gurau, V., Liu, H. T., \& Kakac, S. (1998). Two-dimensional model for proton exchange membrane fuel cells. Aiche Journal, 44(11), 2410-2422. https://doi.org/10.1002/aic.690441109

Imbrioscia, G. M., \& Fasoli, H. J. (2014). Simulation and study of proposed modifications over straight-parallel flow field design. International Journal of Hydrogen Energy, 39(16), 8861-8867. https://doi.org/10.1016/j.ijhydene.2013.11.079

Ju, H., Meng, H., \& Wang, C. Y. (2005). A single-phase, non-isothermal model for PEM fuel cells. International $\begin{array}{lllll}\text { Journal of Heat and Mass Transfer, } & \text { 48(7), }\end{array}$ https://doi.org/10.1016/j.ijheatmasstransfer.2004.10.004

Khazaee, I., \& Sabadbafan, H. (2016a). Effect of humidity content and direction of the flow of reactant gases on water management in the 4-serpentine and 1-serpentine flow channel in a PEM (proton exchange membrane) fuel cell. Energy, 101, 252-265. https://doi.org/10.1016/j.energy.2016.02.026

Khazaee, I., \& Sabadbafan, H. (2016b). Numerical study of changing the geometry of the flow field of a PEM fuel cell. Heat and Mass Transfer, 52(5), 993-1003. https://doi.org/10.1007/s00231-015-1621-4

Kone, J. P., Zhang, X., Yan, Y., Hu, G., \& Ahmadi, G. (2017a). CFD modeling and simulation of PEM fuel cell using OpenFOAM. Paper presented at the Applied Energy Symposium and Forum, REM2017: Renewable Energy Integration with Mini/Microgrid, Tianjin, China.

Kone, J. P., Zhang, X., Yan, Y., Hu, G., \& Ahmadi, G. (2017b). Three-dimensional multiphase flow computational fluid dynamics models for proton exchange membrane fuel cell: A theoretical development. The Journal of Computational Multiphase Flows, 9(1), 3-25. https://doi.org/10.1177/1757482X17692341

Laoun, B., Naceur, M. W., Khellaf, A., \& Kannan, A. M. (2016). Global sensitivity analysis of proton exchange membrane fuel cell model. International Journal of Hydrogen Energy, 41(22), 9521-9528. https://doi.org/10.1016/j.ijhydene.2016.04.046

Liu, Z. (2012). Fuel cell performance. New York: Nova Science Publishers. 
Lozano, A., Valino, L., Barreras, F., \& Mustata, R. (2008). Fluid dynamics performance of different bipolar plates - Part II. Flow through the diffusion layer. Journal of Power Sources, 179(2), 711-722. https://doi.org/10.1016/j.jpowsour.2007.12.095

Mustata, R., Valino, L., Barreras, F., Gil, M. I., \& Lozano, A. (2009). Study of the distribution of air flow in a proton exchange membrane fuel cell stack. Journal of Power Sources, 192(1), 185-189. https://doi.org/10.1016/j.jpowsour.2008.12.083

Nam, J. H., \& Kaviany, M. (2003). Effective diffusivity and water-saturation distribution in single- and two-layer PEMFC diffusion medium. International Journal of Heat and Mass Transfer, 46(24), 4595-4611. https://doi.org/10.1016/s0017-9310(03)00305-3

Nguyen, T. V., \& White, R. E. (1993). A water and heat management model for proton-exchange-membrane fuelcells. Journal of the Electrochemical Society, 140(8), 2178-2186. https://doi.org/10.1149/1.2220792

O'Hayre, R. P., Cha, S. W., Colella, W., \& Prinz, F. B. (2006). Fuel Cell Fundamentals. New Jersey: John Wiley \& Sons.

Osanloo, B., Mohammadi, A., A., \& Solati, A. (2016). A numerical analysis on the effect of different architectures of membrane, CL and GDL layers on the power and reactant transportation in the square tubular PEMFC. International Journal of Hydrogen Energy, 41(25), 10844-10853. https://doi.org/10.1016/j.ijhydene.2016.04.228

Ozen, D. N., Timurkutluk, B., \& Altinisik, K. (2016). Effects of operation temperature and reactant gas humidity levels on performance of PEM fuel cells. Renewable \& Sustainable Energy Reviews, 59, 1298-1306. https://doi.org/10.1016/j.rser.2016.01.040

Parthasarathy, A., Dave, B., Srinivasan, S., Appleby, A. J., \& Martin, C. R. (1992). The platinum microelectrode nafion interface - an electrochemical impedance spectroscopic analysis of oxygen reduction kinetics and nafion characteristics. Journal of the Electrochemical Society, 139(6), 1634-1641. https://doi.org/10.1149/1.2069469

Poling, B. E., Prausnitz, J. M., \& O'Connell, J. P. (2000). The Properties of Gases and Liquids (5th ed.). New York: McGraw-Hill.

Sezgin, B., Caglayan, D. G., Devrim, Y., Steenberg, T., \& Eroglu, I. (2016). Modeling and sensitivity analysis of high temperature PEM fuel cells by using Comsol Multiphysics. International Journal of Hydrogen Energy, 4l(23), 10001-10009. https://doi.org/10.1016/j.ijhydene.2016.03.142

Sivertsen, B. R., \& Djilali, N. (2005). CFD-based modelling of proton exchange membrane fuel cells. Journal of Power Sources, 141(1), 65-78. https://doi.org/10.1016/j.jpowsour.2004.08.054

Springer, T. E., Zawodzinski, T. A., \& Gottesfeld, S. (1991). Polymer electrolyte fuel-cell model. Journal of the Electrochemical Society, 138(8), 2334-2342. https://doi.org/10.1149/1.2085971

Todd, B., \& Young, J. B. (2002). Thermodynamic and transport properties of gases for use in solid oxide fuel cell modelling. Journal of Power Sources, 110(1), 186-200. https://doi.org/10.1016/s0378-7753(02)00277-x

Valino, L., Mustata, R., \& Duenas, L. (2014). Consistent modeling of a single PEM fuel cell using Onsager's principle. International Journal of Hydrogen Energy, 39(8), 4030-4036. https://doi.org/10.1016/j.ijhydene.2013.09.145

Valino, L., Mustata, R., Gil, M. I., \& Martin, J. (2010). Effect of the relative position of oxygen-hydrogen plate channels and inlets on a PEMFC. International Journal of Hydrogen Energy, 35(20), 11425-11436. https://doi.org/10.1016/j.ijhydene.2010.07.052

Velisala, V., \& Srinivasulu, G. N. (2018). Numerical Simulation and Experimental Comparison of Single, Double and Triple Serpentine Flow Channel Configuration on Performance of a PEM Fuel Cell. Arabian Journal for Science and Engineering, 43(3), 1225-1234. https://doi.org/10.1007/s13369-017-2813-7

Wang, Y., Chen, K. S., \& Cho, S. C. (2013). PEM fuel cells: thermal and water management fundamentals. New York: Momentum Press.

Wang, Y. L., Wang, S. X., Wang, G. Z., \& Yue, L. K. (2018). Numerical study of a new cathode flow-field design with a sub-channel for a parallel flow-field polymer electrolyte membrane fuel cell. International Journal of Hydrogen Energy, 43(4), 2359-2368. https://doi.org/10.1016/j.ijhydene.2017.11.172 
Weber, A. Z., Borup, R. L., Darling, R. M., Das, P. K., Dursch, T. J., Gu, W. B., .. Zenyuk, I. V. (2014). A Critical Review of Modeling Transport Phenomena in Polymer-Electrolyte Fuel Cells. Journal of the Electrochemical Society, 161(12), F1254-F1299. https://doi.org/10.1149/2.0751412jes

Welty, J. R., Wicks, C. E., Wilson, R. E., \& Rorrer, G. L. (c2008). Fundamentals of Momentum, Heat, and Mass Transfer (5th ed.). Hoboken, N. J.: Wiley.

Wilberforce, T., El-Hassan, Z., Khatib, F. N., Al Makky, A., Mooney, J., Barouaji, A., ... Olabi, A. G. (2017). Development of Bi-polar plate design of PEM fuel cell using CFD techniques. International Journal of Hydrogen Energy, 42(40), 25663-25685. https://doi.org/10.1016/j.ijhydene.2017.08.093

Wu, H. W. (2016). A review of recent development: Transport and performance modeling of PEM fuel cells. Applied Energy, 165, 81-106. https://doi.org/10.1016/j.apenergy.2015.12.075

Xing, L., Cai, Q., Xu, C. X., Liu, C. B., Scott, K., \& Yan, Y. S. (2016). Numerical study of the effect of relative humidity and stoichiometric flow ratio on PEM (proton exchange membrane) fuel cell performance with various channel lengths: An anode partial flooding modelling. Energy, 106, 631-645. https://doi.org/10.1016/j.energy.2016.03.105

Xing, L., Liu, X., Alaje, T., Kumar, R., Mamlouk, M., \& Scott, K. (2014). A two-phase flow and non-isothermal agglomerate model for a proton exchange membrane (PEM) fuel cell. Energy, 73, 618-634. https://doi.org/10.1016/j.energy.2014.06.065

Yaws, C. L. (2009). Yaws' Handbook of Thermodynamic Properties for Hydrocarbons and Chemicals Retrieved from http://app.knovel.com/hotlink/toc/id:kpYHTPHC09/yaws-handbook-thermodynamic/yaws-handbookthermodynamic

Yaws, C. L. (2012). Yaws' Critical Property Data for Chemical Engineers and Chemists. Retrieved from https://app.knovel.com/web/toc.v/cid:kpYCPDCECD/viewerType:toc/root_slug:yaws-critical-property

Yuan, W., Tang, Y., Pan, M. Q., Li, Z. T., \& Tang, B. (2010). Model prediction of effects of operating parameters on proton exchange membrane fuel cell performance. Renewable Energy, 35(3), 656-666. https://doi.org/10.1016/j.renene.2009.08.017

Zehtabiyan-Rezaie, N., Arefian, A., Kermani, M. J., Noughabi, A. K., \& Abdollahzadeh, M. (2017). Effect of flow field with converging and diverging channels on proton exchange membrane fuel cell performance. Energy Conversion and Management, 152, 31-44. https://doi.org/10.1016/j.enconman.2017.09.009

Zhao, D. D., Dou, M. F., Zhou, D. M., \& Gao, F. (2016). Study of the modeling parameter effects on the polarization characteristics of the PEM fuel cell. International Journal of Hydrogen Energy, 41(47), 2231622327. https://doi.org/10.1016/j.ijhydene.2016.09.112

\section{List of symbols}

$\begin{array}{ll}A & \text { area }\left(\mathrm{m}^{2}\right) \\ C & \text { concentration }(\mathrm{mol} \mathrm{m}-3) \\ C_{r} & \text { condensation rate }\left(\mathrm{s}^{-1}\right) \\ c_{p} & \text { specific heat capacity }\left(\mathrm{J} \mathrm{kg}^{-1} \mathrm{~K}^{-1}\right) \\ d & \text { diameter }(\mathrm{m}) \\ D & \text { diffusivity }\left(\mathrm{m}^{2} \mathrm{~s}^{-1}\right) \\ E & \text { potential }(\mathrm{V}) \\ F & \text { Faraday's constant }\left(96485 \mathrm{C} \mathrm{mol}^{-1} \mathrm{e}^{-}\right) \\ \Delta G & \text { Gibbs free energy }\left(\mathrm{kJ} \mathrm{mol}^{-1}\right) \\ H & \text { latent heat }\left(\mathrm{J} \mathrm{kg}^{-1}\right) \\ \Delta H & \text { enthalpy of formation }\left(\mathrm{J} \mathrm{mol}^{-1}\right) \\ I & \left.\text { current density }(\mathrm{A} \mathrm{m})^{-2}\right) \\ I_{0} & \text { Exchange current density }\left(\mathrm{A} \mathrm{m}^{-2}\right) \\ k & \text { thermal conductivity }\left(\mathrm{W} \mathrm{m}^{-1} \mathrm{~K}^{-1}\right) \\ K & \text { permeability }\left(\mathrm{m}^{2}\right) \\ M & \text { molar mass }\left(\mathrm{kg} \mathrm{kmol}{ }^{-1}\right)\end{array}$




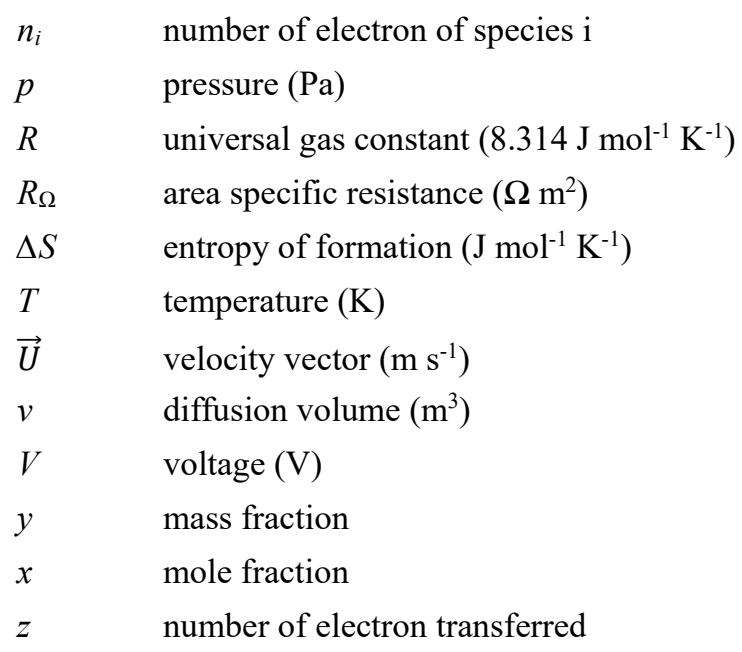

Greek letters

$\alpha \quad$ charge transfer coefficient

$\delta \quad$ thickness (m)

$\varepsilon \quad$ porosity

$\theta \quad$ contact angle (deg)

$\eta \quad$ overpotential (V)

$\mu \quad$ dynamic viscosity (Pa s)

$\xi \quad$ stoichiometric ratio

$\rho \quad$ density $\left(\mathrm{kg} \mathrm{m}^{-3}\right)$

$\sigma \quad$ surface tension $\left(\mathrm{N} \mathrm{m}^{-1}\right)$

$\sigma_{e} \quad$ electrical conductivity $\left(\mathrm{S} \mathrm{m}^{-1}\right)$

$\sigma_{i} \quad$ ionic conductivity $\left(\mathrm{S} \mathrm{m}^{-1}\right)$

$\tau \quad$ tortuosity

Subscripts and superscripts

act activation

c cathode

ch channel

E energy

eff effective

$\mathrm{H}_{2} \quad$ hydrogen

$\mathrm{H}_{2} \mathrm{O}$ water

i species $\mathrm{i}$

j species j

knud Knudsen

$1 \quad$ liquid

L limiting

M momentum

MEA membrane electrode assembly

MEM membrane

mix mixture

$\mathrm{N}_{2} \quad$ nitrogen 


$\begin{array}{ll}\mathrm{O}_{2} & \text { oxygen } \\ \mathrm{p} & \text { pore } \\ \mathrm{PC} & \text { phase change } \\ \text { reac } & \text { reaction } \\ \text { ref } & \text { reference } \\ \text { sat } & \text { saturation } \\ \mathrm{WV} & \text { water vapour }\end{array}$

\section{Copyrights}

Copyright for this article is retained by the author(s), with first publication rights granted to the journal.

This is an open-access article distributed under the terms and conditions of the Creative Commons Attribution license (http://creativecommons.org/licenses/by/4.0/). 